\title{
Lima Bean Production in California
}

\section{BABY AND LARGE}

\section{California lima Beans}

\begin{tabular}{|c|}
\hline CONTENTS \\
\hline California Lima Beans ..... . \\
\hline Variety Selection. . \\
\hline Choice of Seed. . . \\
\hline Land Selection . . \\
\hline Fertilization. .... \\
\hline Crop Rotation . ............ \\
\hline Land Preparation .... . \\
\hline Planting ... \\
\hline Weed Control . \\
\hline Cultivation .................11 \\
\hline Irrigation. ............. \\
\hline Diseases ............... \\
\hline Insects and Spider Mites . . . . . . . 18 \\
\hline Nematodes................21 \\
\hline Harvesting $\ldots \ldots \ldots \ldots \ldots \ldots .21$ \\
\hline Cleaning, Grading, and Marketing . .23 \\
\hline References................23 \\
\hline Measurement Conversion Table . . . .24 \\
\hline
\end{tabular}

ima beans are a major dry bean crop for California, representing a significant portion of the total -dry bean acreage in 2013 (fig. 1). Lima beans are primarily grown for the dried edible white bean in California, although a limited but stable acreage is also for seed production. As with all dry beans, limas are a nutritional and healthy food choice, being an excellent source of protein, fiber, vitamins, and minerals. Lima beans are also an important rotation crop for farmers because the plants fix nitrogen, add biomass to the soil, and require relatively few pesticides.

Lima beans belong to the species Phaseolus lunatus, which is distinct from P. vulgaris, the common bean. Two market classes exist, baby (small) limas and large limas. Both classes have varieties with vine- and bush-type growth habits. Baby lima beans are direct descendants of a Mesoamerican subgroup that exhibits more heat tolerance than the large lima types that are descended from an Andean subgroup. The unique origin of these two genetically distinct subgroups has an impact on our California dry bean industry today.

Lima beans are primarily grown as a single summer crop in the Sacramento and San Joaquin Valleys, with baby limas produced in the warmer areas north and south of the bay delta and large limas in the south delta area, which has a slightly longer and drier harvest season and cooler night temperatures during flowering and pod filling. Lima acreage in historical production areas of the California central coast



Lima beans (large and baby). Photo: E. Kilmartin.

RACHAEL LONG, UC Cooperative Extension Farm Advisor, Yolo County; STEVE TEMPLE, UC Cooperative Extension Plant Sciences Specialist Emeritus, UC Davis; ROLAND MEYER, UC Cooperative Extension Soils Specialist Emeritus, UC Davis; LARRY SCHWANKL, UC Cooperative Extension Irrigation Specialist, Kearney Agricultural Research and Extension Center; LARRY GODFREY, UC Cooperative Extension Entomology Specialist, UC Davis; MICK CANEVARI, UC Cooperative Extension Farm Advisor Emeritus, San Joaquin County; PHILIP ROBERTS, Professor of Nematology, UC Riverside; PAUL GEPTS, Professor, Plant Sciences, UC Davis 


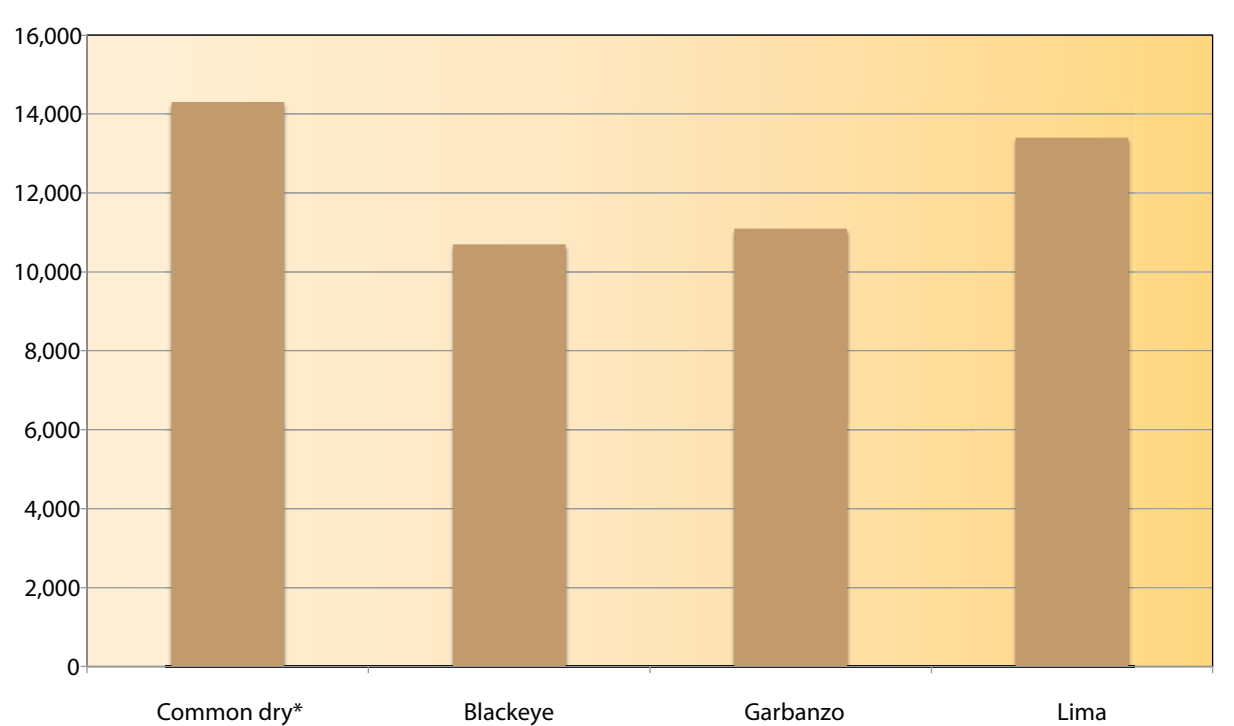

Figure 1. Lima bean acreage compared with common dry beans, blackeye cowpeas, and garbanzos in California, 2013. Source: USDA-NASS.

Note: *Includes kidney, cranberry, black, pink, pinto, and other miscellaneous varieties.

has continued to decrease as land values have increased and other higher value crops, such as grapes, have replaced traditional acreage.

California lima beans are generally grown under contract with marketing warehouses. For large lima beans (fig. 2) and baby limas (fig. 3), acreage has declined due to competition with other higher-value crops, but prices have increased, albeit unevenly. Markets for California lima beans include the canning industry, the retail packaging industry, and international export (primarily to Japan).

More information on the varieties and marketing of dry beans can be found through the California Bean Shippers Association (http://www.calbeanshippers.org) and associated handlers, warehouses, and exporters. Growers and warehouses pay an assessment to the California Dry Bean Advisory Board, a marketing order providing funding for research and promotion of California-produced dry beans.



Acreage $(\times 1,000)$

Yield $(\mathrm{lb} / \mathrm{ac}, \times 100)$

Price (US $\$ / c w t)$

Figure 2. Large lima acreage, yield, and price in California, 2004-2013. Source: USDA-NASS and the California Dry Bean Advisory Board.

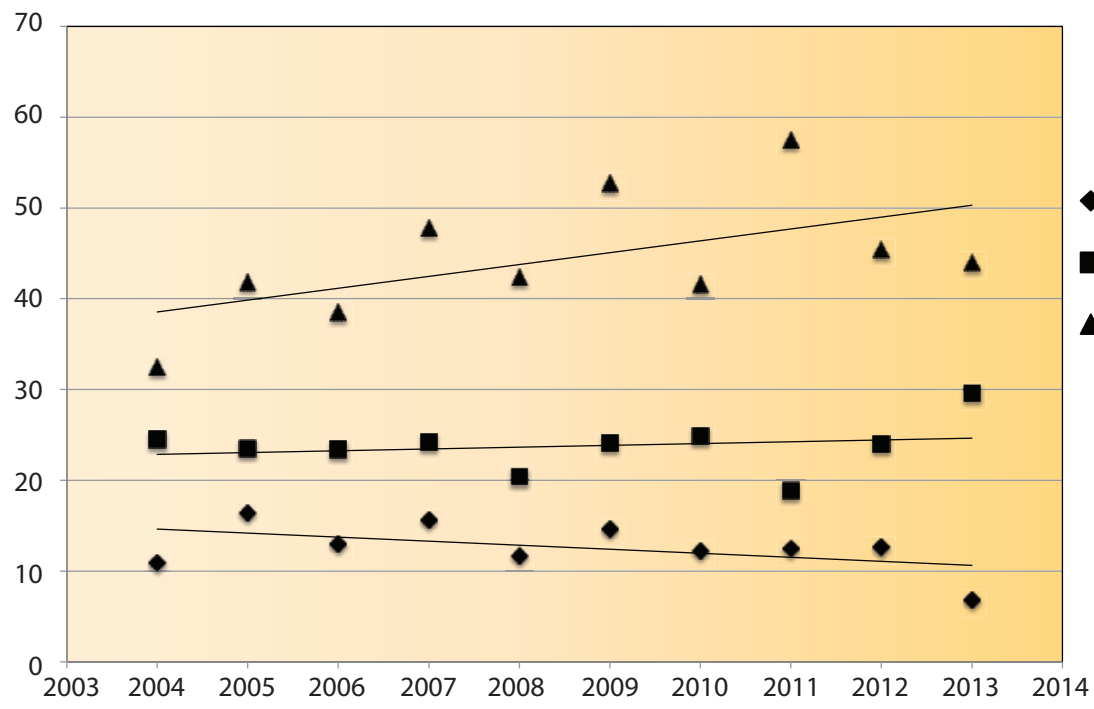

- Acreage $(\times 1,000)$

Yield $(\mathrm{lb} / \mathrm{ac}, \times 100)$

$\Delta$ Price (US \$/cwt)

Figure 3. Small (baby) lima acreage, yield, and price in California, 20042013. Source: USDA-NASS and the California Dry Bean Advisory Board. 


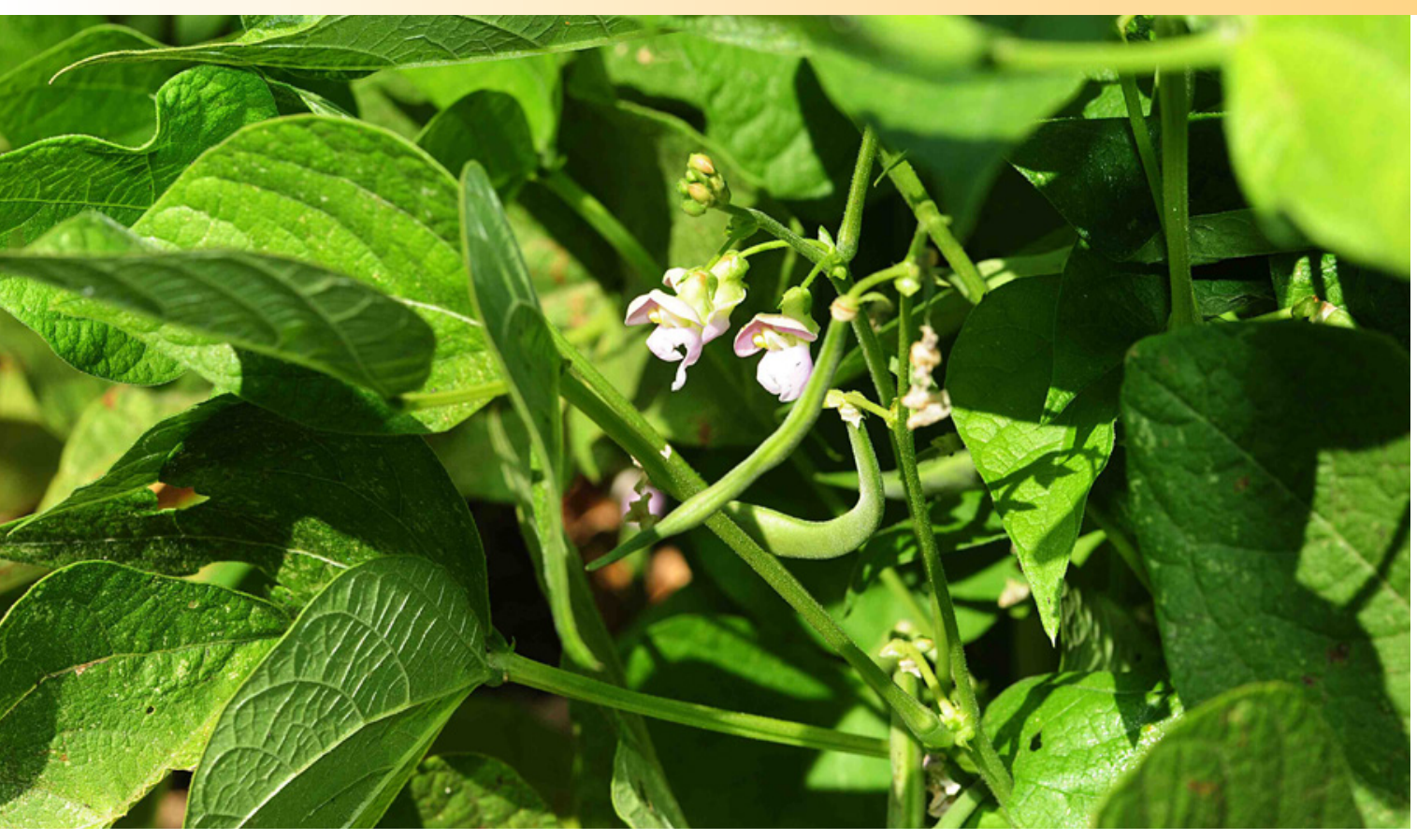

Lima beans (pod and flower). Photo: K. K. Garvey.

Table 1. Characteristics of lima bean cultivars grown in California

\begin{tabular}{|c|c|c|c|c|}
\hline \multirow[b]{2}{*}{$\begin{array}{l}\text { Market class and } \\
\text { variety }\end{array}$} & \multicolumn{2}{|c|}{ Plant characteristics } & \multicolumn{2}{|c|}{ Pest resistance } \\
\hline & $\begin{array}{l}\text { Growth } \\
\text { habit }\end{array}$ & Days to maturity* & $\begin{array}{l}\text { Root-knot } \\
\text { nematode }\end{array}$ & Lygus (tolerance) \\
\hline \multicolumn{5}{|l|}{ large lima } \\
\hline $\begin{array}{l}\text { Dompe } 95 \\
\text { UC } 92\end{array}$ & $\begin{array}{l}\text { bush } \\
\text { bush }\end{array}$ & $\begin{array}{l}\text { medium } \\
\text { medium }\end{array}$ & $\begin{array}{l}\text { susceptible } \\
\text { resistant }^{+}\end{array}$ & $\begin{array}{l}\text { poor } \\
\text { poor }\end{array}$ \\
\hline UC White Ventura N & vine & late & resistant $^{\dagger}$ & very poor \\
\hline \multicolumn{5}{|l|}{ baby lima } \\
\hline $\begin{array}{l}\text { Luna } \\
\text { UC Beija-Flor }\end{array}$ & $\begin{array}{l}\text { bush } \\
\text { bush }\end{array}$ & $\begin{array}{l}\text { early-medium } \\
\text { early-medium }\end{array}$ & $\begin{array}{l}\text { susceptible } \\
\text { resistant }^{\ddagger}\end{array}$ & $\begin{array}{l}\text { fair } \\
\text { good }\end{array}$ \\
\hline $\begin{array}{l}\text { Mezcla } \\
\text { UC Haskell } \\
\text { UC Cariblanco N }\end{array}$ & $\begin{array}{l}\text { vine } \\
\text { vine } \\
\text { vine }\end{array}$ & $\begin{array}{l}\text { medium } \\
\text { medium } \\
\text { medium-late }\end{array}$ & $\begin{array}{c}\text { susceptible } \\
\text { susceptible } \\
\text { resistant }^{\ddagger}\end{array}$ & $\begin{array}{l}\text { very poor } \\
\text { good } \\
\text { very poor }\end{array}$ \\
\hline
\end{tabular}

Notes: See the insect and spider mite section for more information.

*Days to maturity, from date of planting to date of cutting, range from 120 to 135 for large limas and 115 to 135 for baby limas. Maturity varies significantly with location, season, and date of planting.

tResistant to Meloidogyne incognita reproduction and root galling.

*Resistant to both $M$. incognita reproduction and root galling and $M$. javanica root galling.

\section{VARIETY SELECTION}

Lima bean varieties or cultivars are continually being evaluated for increased yield potential, pest and disease resistance, and improved seed quality. UC researchers have developed new lima varieties by adding desirable features to older cultivars or creating new and better cultivars through the recombination of the best traits from available germplasm. This breeding process has been carried out through conventional hybridization and selection of specific traits, not through genetic engineering.

In choosing a lima bean variety for planting, it is important to select for disease resistance, plant growth habit, days to maturity, seed quality, yield potential, and market potential. Characteristics of lima bean cultivars grown in California and their pest and disease ratings are shown in table 1 . The dry bean industry, including warehouses that are dealers of dry edible beans (processing, shipping, and exporting), can also provide assistance in selecting lima bean varieties (consult your nearest warehouse or the California Bean Shippers Association).

Plant growth habit refers to the two basic plant types found in dry edible beans: determinate (bush) type or indeterminate (vine) type. In the determinate bush type, stem elongation ceases when the terminal flowers of the main stem or lateral branches have developed. In vine types, flowering and pod filling continue simultaneously or alternately for a longer period than in bush types. Most vine types tend to be more prostrate than bush types, and they produce branches with runners along the soil level.

Days to maturity refers to the range in number of days from date of planting to date of cutting. Another 1 to 2 weeks are needed for the crop to dry prior to harvest (depending on seasonal conditions at cutting). Lima bean maturity varies significantly with location, season, and date of planting. In general, the number of days to maturity for large limas ranges from 120 to 135 and for baby limas, 115 to 135 . 


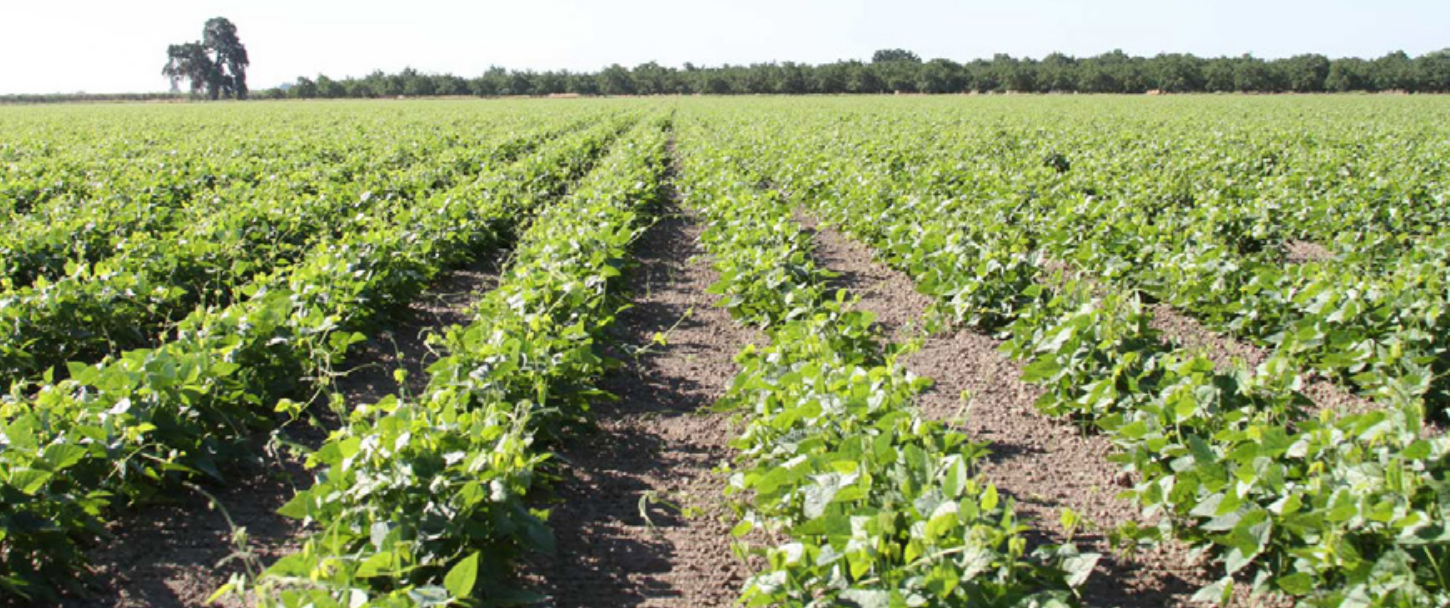

Established lima bean field. Photo: Courtesy of the California Dry Bean Advisory Board.

\section{Choice OF Seed}

Lima bean planting stock should be selected from lots that meet high-performance standards, with seed germination of 85 percent or better and seedlings with no visible defects in germination tests. Planting seed should be free of varietal mixtures, weed seeds, and foreign matter. The use of certified seed ensures the best quality and minimizes the possibility of introducing seedborne diseases. Serious diseases can be introduced, especially from bean seeds either from within or outside California that are not certified, resulting in significant yield losses. Most lima bean planting seed comes pretreated with fungicides to reduce damping-off from Rhizoctonia, Pythium, and other pathogens. Planting earlier than May in cooler soils increases the likelihood of soilborne root or seedling diseases and occasionally of stand loss due to feeding by seedcorn maggot larvae (Delia platura).

When the seed arrives, handle the bags carefully since bean seeds are fragile and internal damage occurs easily. Walking on bags, throwing or dropping them, or pouring the seed into hoppers from distances in excess of 2 feet can cause internal (cryptic) seed injury. Badly bent or curved seedlings, missing cotyledons, and "bald head" seedlings result from seed injury. High-quality seed will germinate rapidly and produce good stands with vigorously growing seedlings.

\section{LAND SELECTION}

Lima beans grow best in deep loamy soils without restrictive clay pans, hardpans, or plow pans in the root zone. Soils that are high in clay content need to be managed carefully, since they may remain saturated for long periods following irrigations. Saturated soils are detrimental to bean growth because water replaces oxygen between the soil particles, resulting in reduced root growth and stand loss. In hot weather, excess water can cause physiological damage to the plants by scalding (flooding and high-temperature injury). The ability of fungi to invade plant tissue is also enhanced by wet soils. Various root rots and wilts of bean plants occur under saturated soil conditions.

Avoid fields with salinity or boron problems. Of the field and vegetable crops grown in California, lima beans are among the least tolerant of salt and boron, as shown in table 2. Lima beans have relatively good root systems. However, if they are grown in soils high in silt, sand, or gravel, which do not absorb or hold moisture well, they may not produce profitable yields. Blackeye cowpea (Vigna unguiculata) is often a better choice for sandy or otherwise poor soils because of its more aggressive root system and moderately better tolerance to salinity and boron. Lima beans

Table 2. Boron and salt tolerance limits of select field crops

\begin{tabular}{|l|c|c|}
\hline Crop & Boron (ppm) & Threshold soil salinity* \\
\hline $\begin{array}{l}\text { lima beans } \\
\text { (P. lunatus) }\end{array}$ & $0.75-1.0$ & 1.5 \\
\hline $\begin{array}{l}\text { common dry beans } \\
\text { (P. vulgaris) }\end{array}$ & $0.50-0.75$ & 1.0 \\
\hline $\begin{array}{l}\text { blackeye or cowpea } \\
\text { (V. unguiculata) }\end{array}$ & 2.5 & 4.9 \\
\hline wheat & $1.0-1.5$ & 6.0 \\
\hline alfalfa & $4-6$ & 2.0 \\
\hline tomatoes & 5.7 & 2.5 \\
\hline
\end{tabular}

Note: *This value is the electrical conductivity of the saturated soil extract, $\mathrm{dS} / \mathrm{m}$ or mmho/cm. 
should always be rotated with other crops, such as wheat, tomatoes, sunflower, and alfalfa, to avoid a buildup of soilborne fungal diseases caused by pathogens such as Rhizoctonia, Fusarium, Pythium, Sclerotium, and Sclerotinia.

\section{FERTILIZATION}

When soils are deficient in nitrogen $(\mathrm{N})$, phosphorus $(\mathrm{P})$, potassium $(\mathrm{K})$, sulfur (S), or zinc (Zn), lima beans are likely to be responsive to these fertilizers. Prior to planting, test the soil from the 0 - to 6-inch depth to determine the likelihood of crop response to $\mathrm{P}$, $\mathrm{K}$, or $\mathrm{Zn}$ fertilizer applications as well as the $\mathrm{pH}$. If there were yield differences within the field of the previous crop, these parts of the field should be sampled separately by taking 12 to 15 cores from the 0- to 6-inch depth and mixing them together to make up each sample. The $\mathrm{pH}$ of a soil should be between 6.0 and 8.0 for good bean production. Lime applications should be considered for soils having a pH below 5.5. Salinity and boron levels should be determined on samples from the 0 - to 6-, 6- to 12-, and 12- to 24-inch depths if there is reason to suspect a salt or boron toxicity problem. Knowledge of field history and past nutrient deficiencies (such as sulfur and boron) or toxicities (such as salt or boron) should be taken into consideration prior to planting lima beans.

Organic production of bean crops involves the addition of manures and other slow-nutrient-release materials that need to be incorporated into the soil prior to planting. Having the results of soil testing mentioned above allows for the development of nutrient management plans. Applying 3 to 5 tons per acre of one of several different types of animal or poultry manure, incorporated several months before planting, often supplies all of the nutrient requirements for the bean crop. The economics of applying other types of acceptable nutrient sources should also be considered. For growers transitioning into organic bean production in soils that require large amounts of phosphorus, potassium, zinc, or possibly lime, it may be more economical to build up the soil fertility by adding synthetic fertilizers and focus on weed and insect control prior to the 3-year transition period to organic production.

\section{Nitrogen}

Lima bean seed has a protein content of about 24 percent and nitrogen $(\mathrm{N})$ content of 4 percent. This means that to achieve a 2,500 pound-per-acre yield, the lima seed crop needs at least 100 pounds of nitrogen per acre. In addition, 30 to 50 pounds per acre of nitrogen are needed for the vegetative portion of the plant. About 20 to 50 percent of the total nitrogen needed will probably be supplied from nitrogen-fixing nodules on the plant roots, but the rest has to come from another source of nitrogen.

Many legumes have the ability to fix nitrogen from the air when inoculated with Rhizobium nitrogen-fixing bacteria. As a result, it is important to inoculate lima bean seed with a hostspecific $R$. phaseoli that includes limas, each time beans are planted, to ensure good nitrogen fixation. Granular inoculant formulations are recommended over powders because they are more effectively applied near fungicide- and insecticide-treated bean seed.

Unlike alfalfa and several other nitrogen-fixing crops, the relationship between some beans and $R$. phaseoli is not able to provide sufficient nitrogen to sustain the highest crop yields. This is generally true of grain legumes, where a large percentage of the plant's nitrogen is found in the seed. Dry, hot weather or periods of soil water saturation further reduce nitrogen fixation. Therefore, nitrogen fertilizers are often needed to ensure that the plant receives enough nitrogen for rapid growth and high yields.

General fertilization of lima beans includes a starter fertilizer of 8-24-6 with 1 to 2 percent $\mathrm{Zn}$ applied as a band during planting, 2 inches below and 2 inches to the side of the seed row at the rate of approximately 100 pounds (dry fertilizer) or 10 gallons (liquid fertilizer of similar analysis) per acre. At layby (prior to row closure by canopy of developing plants), fields should be sidedressed during cultivation with aqua ammonia or a similar nitrogen fertilizer. This should be done at a rate suggested by soil sampling for available nitrate nitrogen about 10 days prior to the sidedress operation and placing the shank 8 to 10 inches deep and 12 to 15 inches away from the bean row 6 to 8 weeks after planting to avoid root pruning (table 3). 
Table 3. Suggested nitrogen fertilizer rates for lima bean yields of 2,500 to 3,000 pounds per acre based on nitrate- $\mathrm{N}$ levels in the top 24-inch soil depth just prior to the planned side-dressing

\begin{tabular}{|c|c|c|}
\hline $\begin{array}{c}\text { Average ppm } \mathbf{N O}_{3}-\mathbf{N} \text { in top } \\
\mathbf{2 4} \text { inches of soil }\end{array}$ & $\begin{array}{c}\text { Average } \mathbf{~ I b ~ N O}_{3}-\mathbf{N} \text { in top } \\
\mathbf{2 4} \text { inches of soil }\end{array}$ & Fertilizer $\mathbf{N}(\mathbf{l b} / \mathbf{a c})$ \\
\hline $0-2$ & $0-16$ & 100 \\
\hline $2.1-4$ & $17-32$ & 80 \\
\hline $4.1-6$ & $33-48$ & 60 \\
\hline $6.1-8$ & $49-64$ & 40 \\
\hline $8.1-10$ & $65-80$ & 20 \\
\hline$>10$ & $>80$ & 0 \\
\hline
\end{tabular}

Table 4. Phosphorus recommendations for lima beans

\begin{tabular}{|c|c|c|c|c|c|}
\hline \multicolumn{6}{|l|}{ Phosphorus (ppm) } \\
\hline Soil test & Very low & Low & Moderate & High & Very high \\
\hline (Bray \#1-P) & $0-5$ & $6-10$ & $11-15$ & $16-20$ & $21+$ \\
\hline (Olsen $\mathrm{HCO}_{3}-\mathrm{P}$ ) & $0-3$ & $4-7$ & $8-11$ & $12-15$ & $16+$ \\
\hline Yield goal (lb/ac) & \multicolumn{5}{|c|}{ Application amount $\left(\mathrm{Ib}_{2} \mathrm{O}_{5} / \mathrm{ac}\right)$} \\
\hline 1,800 & 35 & 25 & 15 & 0 & 0 \\
\hline 2,000 & 40 & 30 & 20 & 10 & 0 \\
\hline 2,200 & 45 & 35 & 20 & 10 & 0 \\
\hline 2,400 & 50 & 40 & 25 & 10 & 0 \\
\hline
\end{tabular}

Table 5. Potassium recommendations for lima beans

\begin{tabular}{|l|c|c|c|}
\hline Potassium (ppm) & \multicolumn{3}{|c|}{} \\
\hline Soil test & Low & Medium & Adequate \\
\hline & $0-40$ & $41-80$ & $81-120+$ \\
\hline Yield goal (lb/ac) & & Application amount (lb K2 $\mathbf{O} / \mathbf{a c})$ \\
\hline 1,800 & 20 & 10 & 0 \\
\hline 2,000 & 20 & 10 & 0 \\
\hline 2,200 & 25 & 15 & 0 \\
\hline 2,400 & 30 & 15 & 0 \\
\hline
\end{tabular}

Residual nitrogen levels in the soil (nitrate- $\mathrm{N}$ in the top 24-inch depth) should be determined about 10 days prior to the planned side-dressing so that the rate of applied nitrogen can be based on soil concentrations just prior to side-dressing. This should be done by taking soil samples ( 8 to 12 cores per sample) from the 0 - to 6-inch, 6- to 12-inch, and 12- to 24-inch depths at two or three locations in each field and requesting analysis for nitrate- $\mathrm{N}$ for each sample. The rate of sidedress-applied nitrogen can be determined according to the concentration of nitrogen in the top 24 inches of soil (see table 3). Another important consideration in nutrient management is the field crop immediately preceding the lima planting. For example, there will usually be much more available $\mathrm{N}$ in the soil following a tomato crop than following corn or wheat.

Nitrogen rates can also be reduced somewhat if the irrigation water contains a high nitrate level. The number of pounds of nitrogen applied per acre-foot of irrigation water is calculated by multiplying the parts per million (ppm) nitrate- $\mathrm{N}$ in the irrigation water times the factor 2.72. Since irrigation water sources vary considerably in nitrate- $\mathrm{N}$ concentration, it is necessary to have the water tested.

\section{Phosphorus}

Phosphorus can be especially important to lima bean production in California because of the relatively early planting dates and cooler soil and air temperatures. If a representative soil test indicates a phosphorus $(\mathrm{P})$ deficiency, apply a starter fertilizer containing this element at the rate indicated in table 4 as pounds of $\mathrm{P}_{2} \mathrm{O}_{5}$ per acre. The soil test using the Olsen bicarbonate $\left(\mathrm{HCO}_{3}-\mathrm{P}\right)$ extract should be used on soils having a $\mathrm{pH}$ of 6.5 or greater, while the Bray \#1-P extract may be used on soils having a $\mathrm{pH}$ less than 6.5. Soil tests showing very low and low extractable phosphorus levels would be expected to show a yield response to phosphorus fertilization. Crops grown in soils that have test levels in the moderate range are less likely to respond to phosphorus fertilizer applications. Adequate phosphorus levels are especially important for strong seedling growth. 


\section{Potassium}

Potassium (K) should be applied as recommended in table 5. Soil test (ammonium acetate exchangeable $\mathrm{K}$ ) results that fall in the low range indicate that plants should respond to potassium fertilization. Test levels in the medium range indicate that the plants are less likely to respond to potassium applications. If a representative soil test indicates potassium deficiency, corrections can be made with a starter fertilizer containing potassium at the rate indicated in table 5 as pounds $\mathrm{K}_{2} \mathrm{O}$ per acre. Few California soils in the lima bean growing areas show yield-limiting potassium deficiencies. Sandy soils would be the first to show potassium fertilizer responses.

\section{Sulfur}

Sulfur (S) deficiencies may be observed in lima beans. Some soils in the Sacramento Valley are likely to be deficient in sulfur, and most irrigation water contains little or no sulfur. Fertilizers such as ammonium sulfate, a common source of sulfur in the past, are no longer used as commonly as non-sulfur-bearing aqua ammonia and other high-analysis fertilizers.

Broadcast and incorporate elemental sulfur into sulfurdeficient soils at a rate of 50 to 100 pounds of sulfur per acre to provide a correction that will last several years. Elemental sulfur (90 to 95\% S) must be applied far enough ahead of planting time to ensure oxidation to sulfate-sulfur, the form used by plants. The time necessary to oxidize elemental sulfur depends on soil temperature and moisture, as well as the size of the sulfur particles applied. Particle size may cause the timeline to change from a few weeks (small particles) to several months (large particles) before the applied elemental sulfur becomes effective. Other materials that provide the readily available sulfate form of sulfur, such as gypsum (calcium sulfate, which is about $17 \% \mathrm{~S}$ ), can also be used. These materials should be applied at a rate that supplies about 25 to 50 pounds of sulfur per acre and should be incorporated into the top 2 to 3 inches of soil to be most effective.

\section{Zinc}

Lima beans often respond to zinc ( $\mathrm{Zn}$ ) fertilizer in low-zinc soils, especially those that test below $0.5 \mathrm{ppm}$ as DTPA-extractable $\mathrm{Zn}$.
These low-zinc soils may occur on soils low in organic matter, calcareous-high pH soils, or on newly leveled land that required extensive cuts and fills. Zinc deficiency may be recognized in bean plants by bronzing, browning, and death of leaf tissue, as well as stunting and poor vining. The best way to diagnose the zinc status of a field is to perform soil tests before planting or to conduct tissue tests of the most recently matured leaves.

The most effective application of zinc is a mixed fertilizer containing zinc at 1 to 3 pounds per acre in the starter fertilizer. If the zinc deficiency is discovered in the growing bean crop, zinc sulfate can be applied to established plants as a foliar spray at a concentration of 3 to 4 pounds per 100 gallons of water to correct a zinc deficiency. A spreader-sticker should be added to the solution, and plants should be sprayed "to wet," which usually requires 10 to 40 gallons of the mix per acre, depending on the size of the plants. Chelated zinc may also be used as a foliar-applied correction.

In fields with severe zinc deficiency, one can apply a correction that will last for several years by incorporating zinc sulfate ( 35 to $36 \% \mathrm{Zn}$ ) into the surface 6 inches of soil at a rate of 10 to 20 pounds of zinc per acre if the soil $\mathrm{pH}$ is less than 7.0. For soils having a $\mathrm{pH}$ greater than 7.0, 20 to 30 pounds of zinc per acre should be applied.

\section{Boron}

A deficiency of boron (B) in bean production is most likely to occur in sandy soils along the east side of the San Joaquin Valley, but it can occur in other locations where soils are inherently low in boron and the irrigation water supplies no boron. Plant symptoms include chlorosis and death of young leaves, dead growing points, and distorted blossom development.

Boron toxicity is likely if dry beans are grown in the high-boron soils on the west side of the San Joaquin Valley, part of Yolo County, and several other areas in California. Soil and irrigation water can be sources of boron toxicity for dry beans. Toxicity symptoms include yellowing of the leaf tips, interveinal chlorosis, and progressive scorching or death of the leaf margins. Lima beans are slightly more tolerant of boron than are common dry beans (P. vulgaris), but they are still sensitive compared to other crops (see table 2). 
A narrow range exists between deficiency and toxicity for boron-sensitive crops, since too much boron reduces yields. Average boron concentrations in the youngest fully mature leaves can be used to estimate plant boron status as follows: deficient (less than 15 ppm boron), sufficient (20 to 50 ppm boron), high (50 to $100 \mathrm{ppm}$ boron), and excessive or toxic (over 100 ppm boron).

The recommendation for soil application of boron is 0.5 to 1 pound per acre, while the suggested rate for foliar application is 0.1 pound of boron per acre mixed in 30 gallons of water. The boron fertilizer used most frequently is sodium borate, which ranges from 10 to 20 percent boron. Solubor is a trade name for a sodium borate that is 20.5 percent boron. This fine granular material is commonly applied as a foliar spray.

\section{Fertilizer Application}

Exercise particular care with starter fertilizer placement to avoid salt damage or ammonia toxicity to the germinating bean seed (do not use urea or diammonium phosphate, [either 18-46-0 or 16-48-0]). No fertilizer should be placed in direct contact with the seed. As a general rule, a monoammonium phosphate (either dry 11-52-0 or liquid 10-34-0) is the preferred fertilizer and should be placed no closer than about 2 inches to the side and about 2 inches below the bean seed.

\section{Crop Rotation}

Lima beans are a warm-season crop. In California's Central Valley, they compete for land with cotton, corn, safflower, wheat, rice, alfalfa, tomatoes, and other vegetable and seed crops such as sunflower and cucurbits, and more recently, orchard crops. They fit well as an intercrop in young orchards until tree growth interferes with dry bean harvesting machinery. Irrigation schedules must also be compatible for both species.

Several disease-producing bean pathogens are either soilborne or come from the bean crop residue. A 3-year crop rotation helps reduce carryover of most disease pathogens that attack lima beans. A good rotation stipulates that dry beans will not be grown in consecutive years. A period of 2 to 3 years between bean crops is highly recommended. Dry beans planted after another bean crop may not do well because diseases caused by pathogens such as Rhizoctonia, Pythium, Macrophomina, Sclerotium, and Sclerotinia tend to build up in the soil. Dry beans following corn, safflower, sunflower, alfalfa, and cereal grains are relatively free of seedling diseases. Most commercial lima planting seed arrives treated with a fungicide to prevent damping off. This seed fungicide generally causes a slight increase in the time from planting to emergence, but some growers confident of limited soil disease pressures choose to plant untreated seed. In a short rotation, dry beans produce best following a cereal crop. The position of dry beans in a rotation may also improve soil tilth and soil nitrogen fertility for the benefit of subsequent crops.

\section{Land Preparation}

Land preparation for limas is generally the same as for corn, sunflower, and other row crops, with the final seedbed free of large clods and in such condition that the planted seed will have contact with fine, firm, moist soil particles to facilitate rapid germination. Consistent seed depth and uniform soil moisture is critical to a good stand. A cloddy field is not only a poor environment for bean seed germination, but herbicides and fertilizers cannot be properly incorporated into cloddy soil.

Primary tillage, which includes subsoiling, discing, land leveling (laser and triplane), and listing beds, is usually done in the fall. The land is subsoiled in two directions to open the soil structure and break up any hardpan. The field is then disced three times to create an adequate seedbed and then leveled in two passes with a triplane. Bed preparation includes listing six rows of 30 -inch beds or three rows of 60 -inch beds per equipment pass. Winter weeds are kept under control around February using Roundup (glyphosate). Dry beans are an interesting component of experimental reduced-tillage systems using semipermanent 60 -inch beds, but dry beans will not tolerate subsoil compaction.

Prior to planting, preplant herbicides (such as Treflan HFP and Dual Magnum) are sprayed onto the soil and mechanically mixed with two passes of a finish disc. A starter fertilizer of 8-24-6 is then applied during planting at the rate of 20 gallons per acre. Afterward, 
the fields are pre-irrigated and then the limas planted. When using power-driven equipment following a pre-irrigation, extreme caution should be used to avoid working the soil when it is wet. If it is too wet, tillage may cause a "slick pan" to develop at seeding depth that will impede root penetration and result in a poor stand, poor seedling development, and reduced plant growth. An excellent and uniform preplant irrigation and careful bed preparation are keys to obtaining a good stand of lima beans. This is especially important because lima beans are slower to germinate than common beans and cowpeas, particularly when planted under cooler soil and air temperatures.

\section{Planting}

Lima beans are planted in single rows on 30 -inch beds or in two rows on 60 -inch beds with a 26 -inch spacing between rows. Planting equipment includes flex-planters or air seeders that are used for other row crops. Avoid cracking or crushing bean seed in the plate planters (specially cut plates may be necessary to obtain the best results). Use a granular Rhizobium inoculant (see the section

Planting lima beans. Photo: Courtesy of the California Dry Bean Advisory Board.

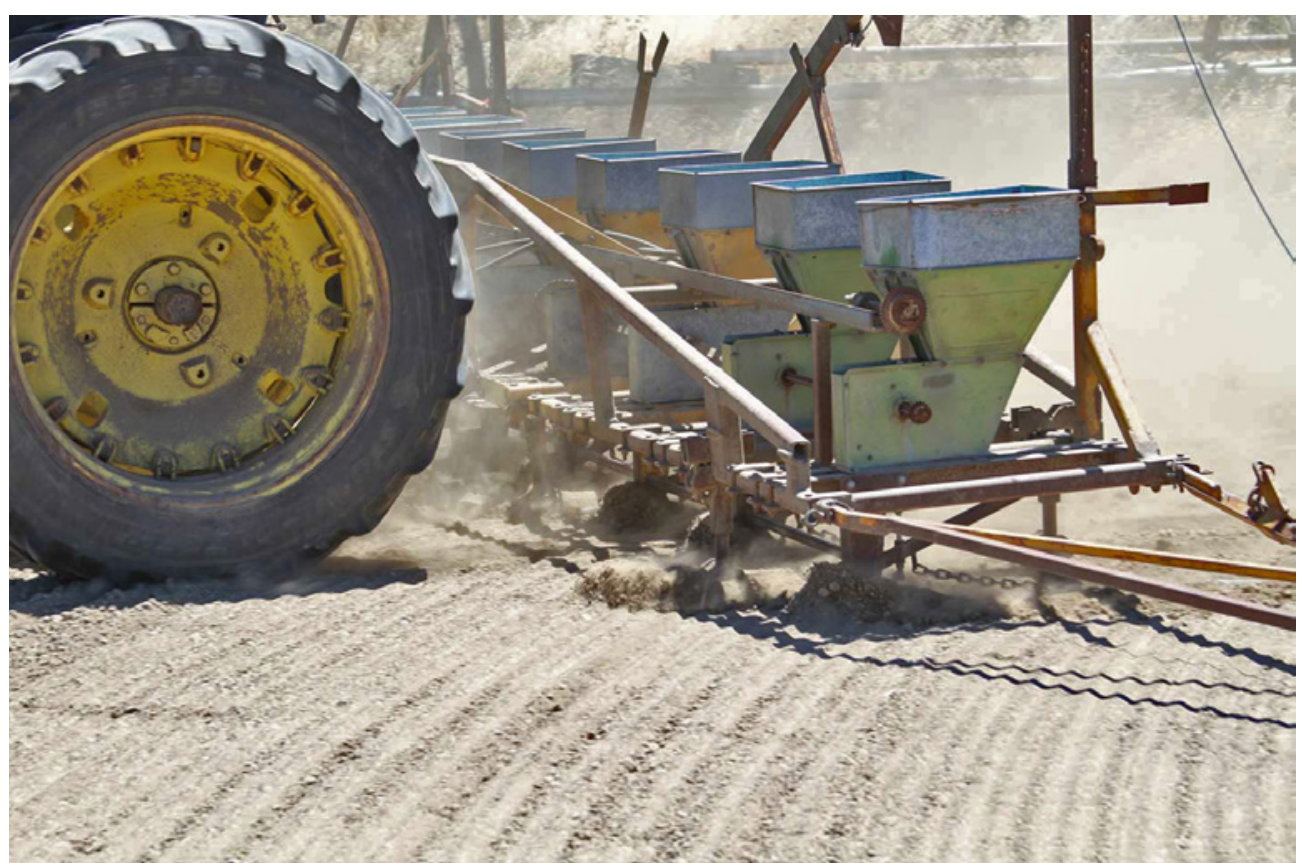

"Fertilization") that is specific to lima beans, and apply it using separate metering boxes attached to the bean planter. These allow the inoculant to pass through separate tubes and shanks that place the substance slightly below and to the side of the planted seed. Powdered inoculant may also be used, but the granular forms are recommended because they are tolerant of fungicide- and insecticide-treated bean seed.

The recommended seeding rate for baby limas is 70 pounds per acre and for large limas 120 pounds per acre. Large limas are planted in May; baby limas are planted in May or June, when warming soils favor rapid emergence (within 7 to 10 days). Pre-irrigate fields and place seed 2 to 4 inches deep into firm, moist soil with no more than an inch of drier soil above the moist soil (use the deeper planting depth if drying winds are a problem or to get into moisture).

If soil moisture is lost after planting, irrigate to germinate the seeds with a very short irrigation set to avoid saturation and seedling disease problems. If crusting occurs over the seedbed after planting, use a lightweight brillion roller to break up the crust to favor seedling emergence and prevent seedling diseases. This operation must be performed before the germinating seed is nearing the soil surface. More stand problems have been observed from planting too deep than from planting too shallow, and most stand problems trace back to preplant practices.

Planting beans into dry soil and irrigating up is sometimes practiced on soils high in clay content or with double-cropped plantings following cereals or other late-harvested crops. A time saving of 8 to 14 days can be gained by this method, but it is somewhat more difficult. Dry beans that are irrigated up have more problems with seedling diseases, and weeds tend to be more of a problem because they germinate at the same time as the beans, making them more difficult to control. If this system is used, beans must not be planted more than 1 to 2 inches deep because poor stands will result from beans being irrigated up if conditions are not ideal. All fields should be level to ensure uniform planting depth and to avoid the accumulation of irrigation water. If beans are irrigated up, sprinkler irrigation will be more successful than furrow for stand establishment. 


\section{Weed Control}

When establishing a lima bean crop, weed control is essential because lima beans are not competitive with early-emerging weeds. It is only after 30 to 40 days of growth that beans become competitive with late-emerging weeds, providing that stands are good. As a result, effective weed control in beans is needed, requiring the integration of cultural practices with the use of herbicides. Since different dry bean classes show different tolerances to herbicides, the guidelines and recommendations in this section are for lima beans only, as other classes may be injured by the herbicides mentioned.

Since most lima beans are planted in late spring, summer weeds and grasses are the major weed competitors. A number of them are especially troublesome, including hairy and black nightshade (Solanum spp.), groundcherry (Physalis spp.), yellow and purple nutsedge (Cyperus spp.), and barnyardgrass (Echinochloa crus-galli). Also challenging to manage are field bindweed (Convolvulus arvensis), annual morningglory (Ipomoea spp.), bermudagrass (Cynodon dactylon), velvetleaf (Abutilon theophrasti), and Johnsongrass (Sorghum halepense). Where lima beans are double cropped behind winter cereals, volunteer wheat and barley may also be of concern.

Weeds are problematic because they shade and crowd bean seedlings and compete for water and nutrients, causing a decline in stands and plant vigor, with a potential yield loss of 10 to 50 percent. Weeds can also decrease the quality of lima beans. For example, when passing through the harvester, nightshade and groundcherry berries produce a dark purple juice that can permanently stain beans, detracting from the visual appearance of the product, especially for light-colored beans. Also, nightshade berries contain poisonous alkaloids, so there is zero tolerance for these berries in beans used for canning. As a result, handweeding crews are sometimes needed to pull and carry out nightshades, which is costly for the grower. Grassy fields also attract armyworms, which are normally not a problem in bean production. Barnyardgrass, with its fibrous root system typical of grasses, may make cutting and threshing at harvest more difficult.

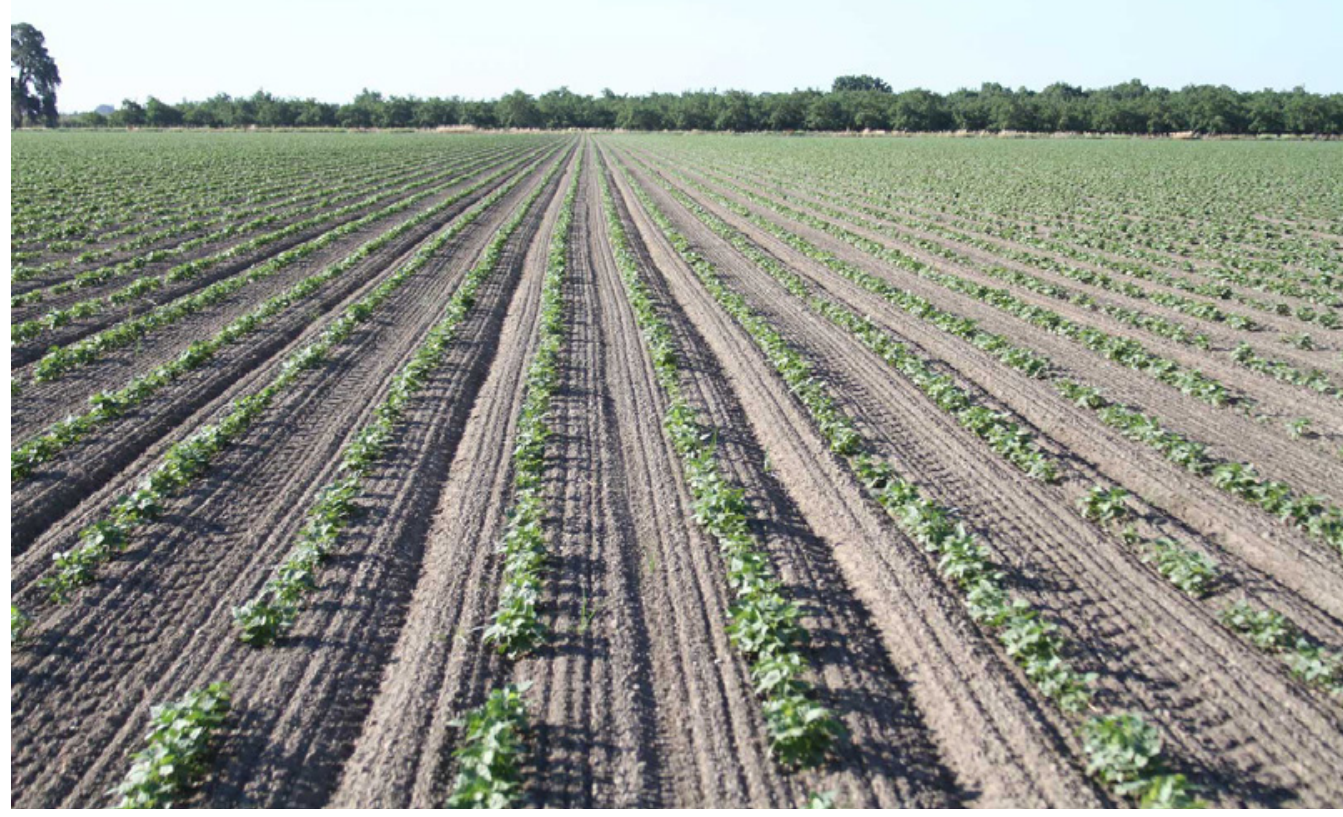

New lima bean stand. Photo: Courtesy of the California Dry Bean Advisory Board.

To help control these weeds, beans should be planted into moisture (from a pre-irrigation) instead of irrigating them up. This will help prevent weeds from germinating at the same time as the beans, decreasing costs for additional cultivation and hand-hoeing labor. Planting into moisture also allows for vigorous seedling development, reducing the incidence of seedling diseases, making the crop more competitive against weeds. Further, a 1- to 2-inch dry mulch of soil over the planted crop reduces weed seed germination until the first irrigation, when the crop is already established. Planting into moisture is most important for organic dry bean production, which would be followed by subsequent cultivations for weed control.

Prior to planting, preemergence herbicides are applied broadcast on preformed beds, followed by incorporation using a rolling cultivator to a depth of about 4 inches (actual placement of herbicide will be half this depth, at about 2 inches, with the beans planted below this zone). A tank mix of Treflan (trifluralin) and Dual Magnum (metolachlor) is often used, as together these 
provide broad-spectrum weed control. Treflan has activity on most broadleaf and grass weeds, but no activity on weeds in the nightshade family or nutsedge, whereas Dual Magnum has activity against the nightshades as well as yellow nutsedge. Dry soils generally result in poor weed control with these preplant incorporated herbicides, so be sure that adequate soil moisture is available for maximum efficacy. During herbicide application, the first tractor pass applies and mixes the herbicide in the soil to a depth of around 1 to 2 inches (spray boom and cultivator attached to tractor). The second pass is required for complete incorporation, either with a disc or rolling cultivator.

Once the beans have germinated and before row closure (from June to early July), two mechanical cultivations are the usual practice for weed control, with one used to sidedress nitrogen into the beds. If weeds have escaped and are problematic, unfortunately there are few postemergence herbicides that can be used in lima bean production. Poast (sethoxydim) and Select Max (clethodim) are effective herbicides against grass weeds, but they must be mixed with a crop-oil concentrate and the spray solution must be buffered if hard or high-pH water is used. Basagran (bentazon) may be used to control emerged broadleaf weeds but can only be applied where sprinklers are used (this herbicide is not approved for use in furrow irrigations). As a result of the limited number of postemergence herbicides available in lima beans, it is very important to invest in weed control early on. Bindweed is a significant weed problem in some fields with a lima/tomato rotation, and bush lima varieties are less competitive with bindweed than are vine limas.

\section{Cultivation}

Lima beans are cultivated to control weeds, to shape beds for cutting, and to improve furrow irrigation and aeration of the root system. This process usually occurs during the fertilizer sidedress operation. Generally, cultivation after the beans have emerged will not conserve soil moisture and may cause severe root pruning if not carefully done. In cases where soils seal badly after an irrigation or crack across beds upon drying, a light cultivation may be beneficial. However, the dangers of root injury cannot be overemphasized, particularly as bean plants approach flowering. Physical damage to plants during cultivation, as well as soil compaction, are other problems associated with excessive or unnecessary cultivations. Throwing dirt toward the emerged or established bean plants may bury some leaves, thus reducing their photosynthetic effectiveness. Also, throwing dirt can pile soil that may be infested with fungi against the plant stems, increasing the potential for disease problems. Tractor speed during cultivation must be monitored carefully to avoid injury to the dry bean crop.

\section{IRRIGATION}

Management of irrigation water is one of the most important factors influencing lima bean yield and quality in the Central Valley. Frequency of crop irrigation depends on plant growth, root development, the water-holding capacity of the soil, and plant water use (evapotranspiration [ET]). Appropriate irrigation water management of lima beans requires proper irrigation scheduling (determining when and how much to irrigate) and good irrigation system management to deliver the desired amount of water efficiently and uniformly.

\section{Irrigation Scheduling of Lima Beans}

\section{Plant appearance}

When soil moisture is low enough to limit rapid crop growth, plants begin to darken in color. When water is applied, the canopy rapidly changes to a lighter color. Canopy color differences are readily seen between moisture-stressed and well-irrigated fields or sections of fields. If bean plants are moisture stressed to the point where the plants turn a dark bluish green, lower leaves will begin to senesce, and flowers and small pods will drop. If lima beans are severely water stressed during the growing season, they will produce lower yields and poorer-quality beans because the weakened plants may not be able to recover from disease problems and physical damage caused by a lack of water. It is always better to perform an irrigation 24 hours in advance of forecast heat waves, and especially during bud formation, flowering, and early pod fill. Do not wait to observe plant stress. 
system was 75 percent efficient, 2.4 inches of water $[(1.8$ in $\div 75) \times$ $100=2.4 \mathrm{in}$ ] would need to be applied. Seasonal irrigation amounts may need to include a pre-irrigation amount. In addition to wetting the seedbed, pre-irrigation stores water in the soil for later use by the crop; however, pre-irrigation can create substantial deep percolation losses since the soil intake rates are high following early-season cultivation. While we would often like to put on a light pre-irrigation, the furrow irrigation system is not capable of doing this unless fields are short and on-flow rates are optimal.

\section{Soil moisture monitoring for lima beans}

Lima beans have relatively limited root systems compared with many other crops. Blackeye beans have a more extensive root system, whereas lima beans are intermediate in rooting depth. While studies have shown that lima bean roots extend to 3 to 4 feet in depth, the effective rooting depth for water uptake is less than that. Vine lima bean root systems are typically deeper and more developed than those

\section{Evapotranspiration irrigation scheduling}

Evapotranspiration (ET) is the amount of water that evaporates from the soil plus the amount transpired by the plant. Daily weather and ET estimates, along with regular soil moisture monitoring, are important for precise water management.

Research and production experience have shown that lima beans grown in the San Joaquin and Sacramento Valleys and irrigated with furrows or sprinklers will require irrigation every 6 to 8 days. The most practical way to describe good irrigation of lima beans is frequent but light. Evapotranspiration of lima beans ranges from 15 to 20 inches per season, depending on the variety and production area. Table 6 shows a typical lima bean ET schedule.

\section{Irrigation amounts for lima beans}

Since no irrigation system is 100 percent efficient, irrigation amounts will exceed the crop ET. Irrigation losses include tailwater losses and deep percolation losses from ditch seepage and overirrigation over all or parts of the field. Once water passes below the root zone of the beans, it is lost to deep percolation. The irrigation amount is determined as follows:

\section{Irrigation amount $=$}

[Crop evapotranspiration $\div$ Irrigation efficiency $(\%)] \times 100$

If the weekly lima bean ET was 1.8 inches and the furrow irrigation

Table 6. Average evapotranspiration (ET) in inches per day for lima beans planted on May 1 and June 1

\begin{tabular}{|c|c|c|c|}
\hline & $\begin{array}{l}\text { Average reference } \\
\mathrm{ET}^{*} \text { (CIMIS) } \\
\text { (in/day during period) }\end{array}$ & $\begin{array}{l}\text { Lima bean } \mathrm{ET}^{\dagger} \\
\text { planted May } 1 \\
\text { (in/day during period) }\end{array}$ & $\begin{array}{l}\text { Lima bean } \mathrm{ET}^{\dagger} \\
\text { planted June } 1 \\
\text { (in/day during period) }\end{array}$ \\
\hline May 1-15 & 0.21 & 0.03 & \\
\hline May 15-31 & 0.24 & 0.08 & \\
\hline Jun 1-15 & 0.25 & 0.15 & 0.04 \\
\hline Jun $16-30$ & 0.27 & 0.25 & 0.10 \\
\hline Jul 1-15 & 0.28 & 0.26 & 0.18 \\
\hline Jul 16-31 & 0.28 & 0.16 & 0.26 \\
\hline Aug 1-15 & 0.27 & 0.11 & 0.23 \\
\hline Aug 16-31 & 0.24 & - & 0.14 \\
\hline Sep 1-15 & 0.21 & - & 0.09 \\
\hline Sep 16-30 & 0.18 & - & - \\
\hline Oct 1-15 & 0.15 & - & - \\
\hline Oct 16-31 & 0.12 & - & - \\
\hline $\begin{array}{l}\text { Seasonal total } \\
\text { (inches) }\end{array}$ & - & 15.8 & 16.0 \\
\hline
\end{tabular}

Notes: *Historical reference crop ET values for area around Patterson, California.

tLima bean crop coefficients used as developed by Ritter and Scarborough 1992. 
of bush varieties. In research at UC Davis, at 1 month after planting (when visual signs of moisture stress were first noted), bean plants had removed about 50 percent of the available soil moisture from the 6-to 12 -inch depth, but at the 3-foot depth only 10 percent of the available moisture was removed.

Irrigation scheduling by monitoring soil moisture is based on the premise that the level of soil moisture influences the lima bean water status. Simply put, if there is plenty of moisture in the soil, the lima bean plant will be well watered. If the soil is dry, the plants will become water stressed. Soil moisture monitoring devices are almost always installed for multiple years and are often referred to as permanent installations.

Two challenges arise when using soil moisture monitoring. First, while very wet and very dry soil water measurement may be obvious, making sense of soil moisture measurements between those two extremes may be challenging. Determining the soil moisture measurement value at which irrigation should occur is often difficult, and the variation in soil moisture according to soil depth can further complicate the determination. Second, the placement of the soil moisture monitoring device(s) can be critical. Placement relative to the plant row, as well as the depth of installation, are factors that affect the soil moisture values. Placement issues can be particularly critical when a localized irrigation system, such as subsurface drip irrigation, is used. Soil moisture monitoring devices are most commonly installed in or near the plant row so that they are not at risk from cultivation or other machinery passing through the field. As a general rule, devices should be installed to the depth of the active root water uptake; and since much of the lima bean water uptake occurs at the shallower depths, monitoring devices should be installed to monitor the water uptake activity at that shallower depth. For example, if it was determined that root activity was to a 3 -foot depth, a good monitoring plan may be to monitor soil moisture at 6 inches, 1 foot, 2 feet, and 3 feet. It may also be useful to monitor at 4 feet to determine whether excess irrigation water is being applied, causing deep percolation past the 3 -foot rooting depth.

Many soil moisture monitoring devices are currently on the market. There are too many to discuss individually, but here are some characteristics to look for when deciding which device to use:

- Display units. Some devices simply display a number relative to some scale. For example, the display may range from 0 (dry) to 100 (wet). You would need to gain experience or rely on field research to determine whether a soil moisture reading (say, "50") was wet or dry for lima beans.

Other devices display soil moisture in units that are more physically based. For example, the display units may express soil moisture in bars of soil moisture tension, percent moisture by volume of soil, percent moisture by weight of soil, inches of moisture per foot of soil, or some other unit. Often, to be truly accurate, these soil moisture monitoring devices need to be field calibrated for the actual soil conditions. Even though the display is in a known physical unit, you may still need to rely on field research or experience to know what the value means. For example, does a value of " 17 percent soil moisture by volume" mean wet or dry soil moisture conditions for lima beans?

- Data logging. When using soil moisture monitoring, it is frequently helpful to keep track of soil moisture readings over time. Graphing such data reveals valuable information, such as where water goes following an irrigation and how much soil water is taken up by the lima beans between irrigations. In addition, such soil moisture information may help determine when it will be time to irrigate next.

\section{Irrigation Systems for Lima Beans}

Lima beans are irrigated in a number of ways in California. Furrow irrigation is the most common method, but sprinklers are used in some areas, especially on shallow soils or soils high in clay content. Subsurface drip irrigation is another option, having advantages such as the ability to irrigate small amounts of water more frequently and overcome surface infiltration problems.

\section{Furrow irrigation}

Furrow irrigation presents challenges to efficiently irrigate lima beans, with two problematic issues in particular. First, it is difficult 
to apply a small amount of water during a furrow irrigation event. The irrigation event has to be long enough to move the water to the field's tail end, and the resulting irrigation amount is often greater than what is needed to refill the crop's root zone. Early in the season when the crop is young and its root zone is limited, the required irrigation amount is small. Frequent, small irrigations are needed. This is difficult to achieve with furrow irrigation unless field lengths are short. Short fields (e.g., 600 feet) are difficult to farm, require more pipeline and ditches compared with longer fields, and are not looked on favorably by growers.

If the furrow irrigation event applies more water than can be held in the lima beans' root zone, water may run off the tail end of the field (tailwater runoff) or pass through the refilled root zone and become drainage or deep percolation water. While some deep percolation may be necessary for salt leaching, excess deep percolation water can leach nitrates, thus causing groundwater contamination and possible under-fertilization of the crop.

A second challenging issue of furrow irrigation is irrigation uniformity. Since water is introduced at the head of the field and therefore has the longest opportunity to infiltrate there, the head of a furrow-irrigated field almost always receives a greater amount of water than does the tail end. Many growers want to make sure that none of the field is under-irrigated, so they manage the furrow system to apply adequate water at the tail end of the field. This results in the head end of the field being over-irrigated, contributing to the likelihood of deep percolation losses.

Improving the performance of a furrow irrigation system can entail both management changes and physical improvements to the system. Management changes include

- irrigating at the correct time (not too early, which could lead to excess deep percolation, and not too late, which could cause crop water stress)

- shutting off water to an irrigation set at the correct time so that the tail end of the field is adequately irrigated but not overirrigated, which can cause excess tailwater runoff and deep percolation
Even with good management of the existing furrow irrigation system, the maximum attainable irrigation efficiency may be lower than desired due to the limitations of the furrow irrigation system. Further irrigation efficiency improvements of the furrow system require that changes be made to the physical system.

The most effective physical change to a furrow irrigation system that can improve irrigation efficiency and uniformity is to shorten the field length. Shortening the field length improves the irrigation uniformity and allows a lesser amount of water to be applied during an irrigation event, improving the irrigation efficiency. While most effective in improving furrow irrigation performance, shortening field length (e.g., cutting a field in half) requires additional supply pipelines or ditches, additional roads to access the fields, and often more tailwater ditches. In addition, shorter fields are substantially harder to farm. For example, shorter fields require equipment to be lifted or turned each time a road is encountered. All of these changes associated with shorter fields cost the grower money, so the irrigation water management improvements need to be balanced against the cost of the changes.

Leveling a furrow-irrigated field is often less expensive than shortening a field, especially if the field was originally land leveled and re-leveling is just returning the field to the original slope. It is common for portions of the field to be out of slope (especially the top and bottom ends of the field, where cultivation equipment turns and piles up the soil or removes it). Land leveling allows water to move more evenly across the field, improving the irrigation uniformity and efficiency. While land leveling can be beneficial, it is not as effective in improving irrigation uniformity as shortening the field length.

Once water reaches the end of the field, it can be allowed to run off, resulting in tailwater runoff. Or sometimes water is held on the field and allowed to run up nearby furrows that may not have advanced to the end of the field yet. However, holding water on the tail end of the field can result in overwatering, thus damaging the crop and increasing deep percolation losses. If tailwater is allowed to run off the field, it should be collected and reused, utilizing a tailwater return system. 


\section{Sprinkler irrigation systems}

Using sprinkler systems for lima bean irrigation provides the water manager with greater control over the amount and timing of irrigations, improving irrigation efficiency. Irrigation uniformity should be high when using a well-designed sprinkler system.

There should be minimal runoff from a sprinkler irrigation system. The sprinkler application rate should be selected so that the applied water infiltrates where it lands. Even on problem soils that may have low infiltration rates, the sprinkler system can be designed with an application rate to match the low infiltration rate, thus minimizing surface runoff.

The manager should know the sprinkler application rate (inches per hour). This can be determined using field measurements such as sprinkler pressures and nozzle size, along with the sprinkler spacing. Alternately, a field catch-can test can be performed to determine the application rate and uniformity of the sprinkler system. Using the application rate and uniformity information in conjunction with the irrigation scheduling information (often ET estimates for the crop), the correct sprinkler operating times can be determined to maximize crop performance and irrigation efficiency.

The major disadvantage of sprinkler irrigation is its cost, which includes the purchase or rental of the sprinkler system as well as the labor cost associated with its use.

\section{Subsurface drip irrigation}

While it is unlikely that it would be economical to install a subsurface drip irrigation (SDI) system to grow only lima beans, it is possible to grow lima beans as part of a rotation on a field that has an SDI system installed for another highervalue crop such as processing tomatoes. The major advantage of the SDI system is the capability of irrigating more uniformly and efficiently. The SDI system allows the user to apply small irrigation amounts frequently, matching crop water use. Using SDI may also have the advantage of reducing weed growth, since the entire field surface is no longer being wetted.
When using SDI in lima beans, the tape spacing (i.e., the distance between lines of drip tape) needs to be appropriate for lima beans. The lateral movement of water from the tape varies by soil type. If the spacing between lines of the drip tape is too great, plants between the tape lines may not receive enough water. Ideally, drip line spacing should be the same as crop spacing, but growers have made other spacings, often wider, work.

A second consideration when using SDI is the installation depth of the drip lines. If the drip tape is to be left in place and reused, it needs to be installed deep enough so that harvest and field preparation activities can be done over the tape. This usually requires the drip tape lines to be at least 8 to 10 inches deep.

The installation depth decision will also take into account issues such as germination as well as the detection and repair of leaks and clogs. If germination using the SDI system is desired, the drip tape should not be installed too deep. While water movement from the tape upward to wet the seedbed is soil dependent, field experience has shown that installation depths of 10 to 12 inches or less will often work for germination. Drip tape installation depths that are greater than this may not adequately wet the seedbed for good germination.

Rodents, especially gophers, are a major problem in SDI systems because they chew the drip tape, resulting in leaks that are often difficult to find and repair. There is some data to suggest that deeper buried drip tape placements may have less gopher damage.

\section{Irrigating Problem Soils}

Furrow irrigation can easily saturate soils high in clay content and create an environment unsuitable for bean roots. Anaerobic (oxygen starved) root conditions are very damaging to limas. Fungi such as Rhizoctonia, Fusarium, and Pythium will infect bean roots in wet soils and reduce stands, vigor, and yield. Use sprinkler irrigation on soils high in clay content to avoid root disease problems. However, this may increase bean production costs and the potential for certain foliar disease problems.

Another approach to irrigating on clay soils is to use a wide bed with furrows formed on 60 -inch centers as opposed to the conventional 30 -inch beds. The beds are shaped flat on top and 
beans are planted in rows 26 inches apart. Irrigation runs should be 600 to 800 feet long, if possible, and never longer than 1,200 feet. This system leaves an area between the rows on the wider beds unsaturated, thereby maintaining oxygen in the soil for the roots. This wide-bed system has no practical application on loamy soils and should not be used on silty soils where water penetration is a problem. Furrow irrigation using 60 -inch beds must be performed carefully to get good moisture penetration to the entire root system without water logging. On 30-inch beds, some growers may irrigate every other row, alternating the furrows irrigated during each irrigation to manage water better on heavy soils or to get through the field faster before a heat spell.

Soils with a high silt content present a challenge for growing lima beans. These soils absorb moisture well after a cultivation, but when silty soils are irrigated a couple of times, they seal and become almost impervious to water penetration. After the bean plants mature and close in the row, cultivating equipment cannot be driven between the rows to open the soil up. Cultivation timing is very important for vine limas, because cultivation damage to runners is a problem earlier in the growing season.

\section{DISEASES}

A number of serious diseases affect lima dry bean yield and quality in California. Those that are seedborne include bean common mosaic virus (BCMV) and bacterial blights. Those that are soilborne include the seedling diseases (caused by Rhizoctonia and Pythium), Fusarium root or dry rot, white mold, and charcoal rot or ashy stem blight. Many of the diseases described in this section are best managed through variety selection and careful cultural practices, which are even more important to follow for organic producers.

\section{Bean Common Mosaic Virus (BCMV)}

$\mathrm{BCMV}$ is an occasional problem in lima bean production, though other diseases and pests are far more important. BCMV is generally introduced into the crop as a seedborne disease that is then spread throughout the crop by aphids. Disease severity depends on the virus strain, percent of the planting seed that is infected, age of plants when infection is spreading, aphid populations, and susceptibility of the cultivar grown. Symptoms generally appear as light and dark green mottled or mosaic patterns on leaves. Other symptoms are leaf cupping with the edges curled downward, smaller than normal leaves, and stunted plants with deformed blossoms and pods. Control of BCMV is easily accomplished by planting certified seed. Control of the aphid vectors with insecticides is not economically viable for preventing BCMV.

\section{Common and Halo Bacterial Blights (Xanthomonas campestris, Pseudomonas syringae)}

Bacterial blights in lima beans are favored by conditions of high moisture and high humidity. Although uncommon in California, these conditions may be found under sprinkler irrigation. Symptoms appear as brown spots surrounded by light green to yellow rings found around the edges or in the interveinal areas of leaves. Under severe disease pressure, the plant may lose its leaves and pods, and seeds may become infected, causing seeds to shrivel and germinate poorly. To control these diseases it is important to plant certified, disease-free seed and practice a 2- to 3-year crop rotation. In addition, for lima beans grown for seed, it is important to grow the crop under furrow or drip irrigation to guarantee seed free of common and halo blights.

\section{Seedling Diseases (Rhizoctonia solani and Pythium spp.)}

$R$. solani is a fungus that is often the cause of postemergence dieback of seedlings. Commonly referred to as root or stem rot, stem canker, hollow stem, or damping-off, symptoms of the pathogen include reddish brown sunken lesions of varying sizes on the germinating seedlings and roots of infected plants. The lesions have well-defined borders that become rough, dry, and pithy as they age. The disease may spread to nearby plants that may not die, but their yields are often reduced. Branches and pods resting on the soil may also become infected. Longer rotations are necessary in fields with heavy Rhizoctonia incidence.

Pythium, a water-loving mold, usually causes preemergence 
rot and dieback of seedlings. Initial symptoms include elongated, water-soaked areas on the lower hypocotyl or roots of seedlings. The lesions become tan to light brown in color and may become slightly sunken. Under wet conditions and warm to high air temperatures, the fungus may spread upward to other parts of the plant.

Most lima bean seed now comes pretreated with fungicides, such as Apron XL (mefenoxam) and Maxim (fludioxonil), to help control seedling diseases. The fungicide seed protectants are applied to the seed by the bean warehouse, and the cost is included in the seed price. Good cultural practices are also very important in preventing root rot. As warm season crops, lima beans should be planted from mid-May to late June, when soils and ambient temperatures are warm enough to favor rapid seed germination and emergence from the soil to help minimize seedling diseases. Other methods for preventing seedling diseases include the use of certified seed, adequate rotation intervals, making sure not to plant too deeply (which may occur when chasing moisture or when planting on uneven beds), and having good soil aeration.

\section{Fusarium Root or Dry Rot (F. solani)}

Fusarium root rot is a fungal disease that is one of the causes of early maturity (also known as "early cut-out") and marked reduction in yield. The first symptom is a slightly reddish coloration of the taproot, which occurs about a week after seedling emergence. As the disease progresses, it eventually covers the entire taproot, extending near the soil surface but rarely above it. As the infection ages, brownish discoloration of reddened areas occurs, frequently with longitudinal fissures in the diseased tissue. The root and lower part of the stem may become pithy. Severely affected plants that are stressed by drought conditions or excessive soil saturation often show leaf yellowing. If conditions for Fusarium root rot occur early in the development of bean plants and are not corrected, plant growth at blossom initiation usually ceases or is greatly reduced. Small plants with yellowing lower leaves, early leaf drop and plant maturity, and low yields are all the result of infected roots that are incapable of providing adequate water at times of high demand. Plants infected with Fusarium root rot are very sensitive to seasonal heat waves.
Control measures for Fusarium root rot include longer rotations ( 6 to 8 years between bean crops), planting tolerant varieties, use of seed treatments with effective fungicides, and planting into warm, uncompacted soils. Soil compaction resulting from seed furrow openers may impede rapid root development and accentuate the disease problem. Management practices that avoid prolonged flooding or water stress and improve soil aeration and root growth in the lima bean crop will tend to reduce the effects of Fusarium root rot. (See above practices for water management, including double beds and skip-row irrigations.)

\section{White Mold (Sclerotinia sclerotiorum and S. trifoliorum)}

White mold is a fungal disease that is favored by moderate to cool temperatures, high moisture (humidity or rainfall), and aging plant tissue. In the Central Valley, this disease is generally observed in late-planted, full-season lima varieties maturing in late September and into October. The disease starts from soilborne sclerotia (i.e., black, irregularly shaped structures of condensed mycelium) that are resistant to decay and allow the fungus to survive in the soil during long periods of unfavorable conditions. With moisture, these sclerotia germinate, producing airborne spores. In a moist canopy, the spores germinate in a water film on plant parts and develop infective white mycelium, fine strands of the fungus. Any part of the plant can become infected.

Symptoms are water-soaked lesions followed by a white, moldy growth on leaves, stems, or pods. As the infected part ages, it takes on a bleached or chalky appearance. Within a few days after the disease establishes, black sclerotia of varying sizes and shapes are formed on and in infected tissue. Using varieties with upright growth habit, wider row spacing, and crop rotation away from susceptible crops will help reduce white mold infection. The crop should be carefully monitored late in the season, and one should be prepared to apply fungicides, such as Endura (boscalid), on short notice. Careful late-season irrigation management is critical to limit this disease. This includes watching the weather, scheduling irrigations only when needed, and being very stingy with the water to avoid over-irrigating with standing water in the furrows. This is 
especially true at night and during cooler temperatures, when there is no evapotranspiration and lots of moisture in the canopy that will favor disease development. The disease can be absolutely limiting for late-planted large limas in areas where September and October night temperatures are low and free moisture is high.

\section{Charcoal Rot or Ashy Stem Blight (Macrophomina phaseolina)}

Macrophomina causes a fungal disease stemming from both a soilborne and seedborne pathogen. In seedlings, symptoms include a conspicuous, black, sunken canker that appears near the base of the cotyledon and spreads downward into the stem and upward toward the first pair of leaves. As the disease progresses, lesions begin at or below the soil level and extend downward into the roots, causing them to turn black, and often upward some distance into the branches. Lesions are somewhat sunken and reddish brown. The older the stem when attacked, the more shallow the canker remains. As lesions enlarge, they turn gray, and minute but distinct black fruiting bodies form in the center of the lesions. These black structures are the most reliable means of identifying this disease. Many infected plants are killed without producing seed or are stunted, which reduces yield.

The fungus is pathogenic on many crops, including corn, sunflowers, and sorghum, and tends to be worse on certain soils. This disease primarily occurs under conditions of drought stress and high temperatures, especially when an irrigation is applied later than needed. Avoid drought stress by applying frequent and light irrigations before crop stress occurs, and especially during periods of high temperature. A 3-year rotation with a cereal crop will also help reduce soil inoculum.

\section{INSECTS AND SPIDER MITES}

The primary pests of lima beans are lygus bugs, summer worms, aphids, and spider mites. Other insect pests include wireworms, leafminers, seedcorn maggots, and leafhoppers. Usually damage from these pests can be prevented if bean fields are inspected regularly and control practices used when damaging pest populations are encountered. As in most field crops, it is important to delay insecticide applications as far into the bean crop season as possible to avoid disruption to beneficial insect populations. In this regard, early infestations of green peach aphid and thrips, while common, almost never impact yield or quality. However, later infestations of the black cowpea aphid can be a serious problem. Regular monitoring is effective in managing pests. For information on pesticides and pest control practices in dry bean production, refer to the University of California Integrated Pest Management (UC IPM) guidelines online (http://ipm. ucdavis.edu/PMG/selectnewpest.beans.html), as well as UC IPM's Color Photo Guide to Dry Bean Pests (ANR Publication 3339PS2).

\section{Lygus Bugs (L. hesperus and L. elisus)}

Lima beans are susceptible to lygus bugs (Lygus spp.), $1 / 4$-inch long insects with piercing, sucking mouthparts. During early bud and flowering stages, lygus bugs cause bud and flower loss, resulting in reduced yields. Lygus bug feeding on young, developing seed pods causes pod distortion, pitting, blemishes on table market beans, and reduce germination in seed beans.

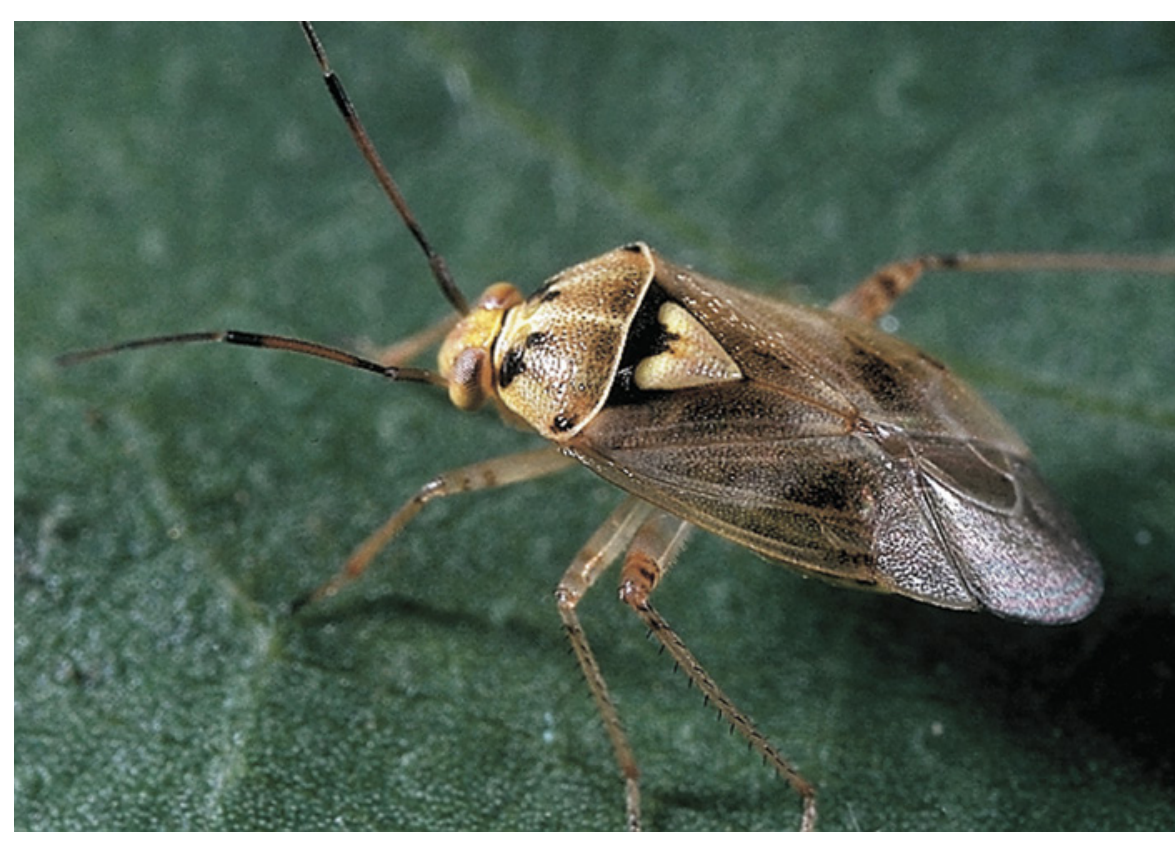

Adult lygus bug. Photo: J. K. Clark. (See also UC IPM Pest Management Guidelines: Color Photo Guide to Dry Bean Pests.) 
Lima bean sensitivity to lygus bugs depends on the cultivar, with some varieties having better lygus tolerance and higher yields than others (see table 1). Seed damage to lighter-colored varieties is the most common danger, and regular field monitoring for this pest will identify this risk. Adjacent safflower and alfalfa fields are likely sources of large lygus populations during bloom, so adjacent lima plantings should be avoided, especially when growing organic lima beans. For organic producers, common dry beans (and especially darker-colored classes of common beans) are much less sensitive to lygus damage.

Monitor lygus bug populations weekly, from floral bud stage until pod fill, using a standard insect sweep net. Take a series of five to ten 180-degree sweeps in six areas of the field. Pass the net through the top of two rows of bean plants (one bed for double-row plantings or two beds for single-row plantings) on each sweep. The threshold for lygus in the UC Luna and UC Beja-Flor bush baby lima varieties, as well as the UC Haskell vine baby lima, is 1.0 to 1.5 bugs (adults plus nymphs) per sweep from bloom to flowering and 1.5 to 2.0 per sweep later in the season. For all other varieties, the threshold is 0.5 lygus per sweep during early bloom and 1.0 to 2.0 bugs per sweep later in season.

Vine lima varieties (for example, Mezcla and White Ventura $\mathrm{N})$ are especially susceptible to lygus. However, these are more difficult to monitor because the huge plant canopy makes it nearly impossible to get into it with a sweep net. Pulling the canopy apart and visually inspecting for lygus activity is highly recommended, along with sweeping. Midmorning evaluations are more accurate than afternoon evaluations, because hot temperatures cause lygus to retreat into the lower sections of the canopy. No good resistance to lygus has been incorporated into large lima varieties to date.

A single pesticide application often suffices for lygus control, as long as pests are monitored and fields treated when economic threshold levels are reached. Lygus has three to four generations per year, with the first generation generally occurring on weeds that surround the fields or, to a lesser extent, in crops such as alfalfa and safflower. When weeds dry down and crops are harvested, lygus bugs migrate into bean fields. Control weeds around fields- especially common mustard (Sinapis arvensis), black mustard (Brassica nigra), and wild radish (Raphanus sativus) - or replace these weeds with native California vegetation that is not favored by lygus bugs, such as perennial grasses that are not hosts for lygus bugs (Long and Anderson 2010).

\section{Corn Earworm (Helicoverpa zea) and Armyworm (Spodoptera exigua and S. praefica)}

The larvae of corn earworm and armyworm feed on leaves, buds, flowers, and within pods, causing damage to seed and yield losses. They are most abundant during the summer months, primarily July to September. To monitor for corn earworm, inspect the sweep net for small worms when sampling for lygus. Although sweeping is not a reliable sampling method to document an infestation, the presence of small worms in the net indicates that a problem may be developing. Shaking plants and inspecting for worms on the ground will also indicate the presence of small worms. The presence of defoliation on the leaves is also an indication that these worm pests may be present. No precise economic threshold has been established for initiating control of corn earworm or armyworm on limas. However, begin treatment when small worms appear in the sweep net and are found on young pods throughout the field. Conventional sprays for lygus control will usually clean up worms in lima fields.

\section{Black Bean Aphid (Aphis fabae) and Cowpea Aphid (A. craccivora)}

Both of these black aphids are distinct from the green peach aphid, which does not warrant control or concern. Feeding damage by black aphids causes leaves to curl, with eventual stunting of plant growth under severe aphid pressure. Aphids also excrete honeydew, a sticky substance that is colonized by a black sooty fungus that may reduce photosynthesis, and they can spread viral diseases such as BCMV (as described in the section "Diseases"). Aphid infestations are usually sporadic in the field and often kept under control by beneficial insects, such as ladybird beetles, lacewings, and syrphid flies. As a result, fields should be monitored for both aphid and 
beneficial insects-and if infestations affect plant growth, they should be controlled.

\section{Spider Mites (Tetranychus spp.)}

Spider mites can cause leaf defoliation and significant yield reductions in lima beans. In the spring spider mites move up from the soil, infesting the lower leaves, and then migrate throughout the plant as it grows. The spread of mites is most severe near field edges, where equipment traffic and dust are significant factors leading to mite problems, and adjacent to fields of drying corn or sunflowers. As a result, it is important to water roads to keep the dust down and minimize traffic and speed, especially for organic production. Earlyseason pyrethroid insecticide applications used to control lygus or occasional seedling insects, such as cucumber beetles (Diabrotica) or thrips (Frankliniella occidentalis), tend to aggravate spider mite problems.

Spider mite colonies can first be found in low numbers on the underside of lower leaves close to the midrib vein. Look for pinpoint-size whitish dots on the upper surface of an infested leaf, indicating the presence of a spider mite colony on the opposite side. When abundant, spider mites cause bean leaves to appear finely stippled over the entire upper surface while the undersurface takes on a gray appearance due to profuse webbing.

Spider mites should be controlled with an acaricide when they are found throughout the field at the pre-bud to early flowering stage. A later population can be treated with the first application for lygus bug control. At any stage of growth, good coverage of the plants is essential to obtaining effective long-season control with one pesticide application. Using drop nozzles that cover the underside of the lower leaves has proved to be consistently better than spraying over the top of the plant. Always check labels for specific instructions if plants are being used for forage after harvest. Spider mites are perhaps the most difficult lima bean insect pest to scout for and to recognize as a problem in a timely way.

\section{Wireworms (Limonius spp.)}

Wireworms are the soil-dwelling larvae of adult click beetles. The larvae injure crops by feeding on germinating seeds in the soil and preventing seedling emergence. They also cut off small underground stems and roots and bore into larger stems and roots, affecting plant growth. Wireworms are commonly found in fields following pasture or weedy alfalfa. Avoid planting dry beans in fields infested with wireworms, which should be identifiable from the monitoring of previous crops. Consider using a seed treatment in fields with a history of wireworm problems.

\section{Leafminers (Liriomyza sativae and L. trifolii)}

The damaging stage of leafminers is that of the larvae (maggots) or the immature stage of tiny adult flies, which are black to blue with a prominent yellow area at the base of the wings. The minute, white eggs are laid just under the leaf epidermis and hatch in 4 to 6 days. The maggots (larvae) are normally concealed between leaf surfaces in the mines where they feed; they range from yellow to white and grow to be about 0.3 inch long. Three to five generations a year are produced. Leafminers are fairly common in lima fields, and they are occasionally a problem during the latter part of the production season. The maggots feed between the upper and lower leaf surfaces, causing large, brown blotches or-in the case of serpentine leafminers-slender, white, winding trails through the interior of the leaf. Outbreaks often occur after applications of insecticides, which kill common parasitoids of the leafminer that often provide good biocontrol of this pest. To check for leafminers, evaluate the amount of mining in the leaves during weekly observations for other insect pests, beginning at crop emergence. Continue to monitor leaves during periods of vegetative growth, flower bud to bloom, and pod fill. Economic thresholds have not been determined for lima beans in California, but research in Peru reported losses of up to 50 percent of the photosynthetically active leaf area before effects on yield were observed. It therefore takes a lot of leafminer damage to impact lima bean yield. 


\section{Seedcorn Maggot (Delia platura)}

The seedcorn maggot is the larval stage of a small fly that lays its eggs in soil. The larvae feed on germinating seeds and seedlings and damage the cotyledons and shoots of developing seedlings, with stand reductions severe in some years. The seedcorn maggot is especially problematic with early spring plantings (slower bean germination) and with damp soils, cool temperatures, and where weed or cover crop matter is decomposing.

To control seedcorn maggot, avoid fields with fresh, decomposing organic materials, and plant under ideal soil and weather conditions to assure rapid seed germination. Consider using an insecticide seed treatment when planting during these conditions or doing a second pre-irrigation to break down decaying crop and weed matter. Adult maggots can be monitored with yellow pan traps. Set out a yellow bowl with an inch or two of water and a few drops of detergent to break the surface water tension. Check traps daily for adult fly maggots, especially after early planted limas following a heavy cover crop or weed residue. Wait to plant until the adult fly maggots begin to decline in numbers.

\section{Leafhoppers (Empoasca spp.)}

Leafhoppers can seriously damage beans if they are not controlled. However, severe leafhopper problems are rare in California. Where leafhoppers are abundant, leaves become tip-burned, turn yellow, and cup or curl downward. Heavily infested plants become stunted and bushy and set little or no seed. Leafhoppers are easily monitored using a sweep net.

\section{Nematodes}

Nematodes are microscopic roundworms that feed on plant roots and cause them to become chlorotic, stunted, necrotic, or wilted. Nematode activity can also open the bean root system to infection by fungal pathogens. Most lima bean varieties are highly susceptible to the common root-knot nematodes Meloidogyne incognita and $M$. javanica, the most damaging plant parasitic nematodes on lima beans. Root-knot nematodes induce galling or swelling of infected roots. The galled tissues, which leak nutrients into the rhizosphere soil, attract secondary pathogens that cause root rotting. In general, lima beans grown on silt loam to clay loam soils are not as heavily infested with root-knot nematodes as those grown in coursetextured (sandier) soils, which favor nematode activity.

Some success has been achieved in breeding lima beans with resistance to root-knot nematodes, and several large and baby lima varieties with nematode resistance are available (see table 1 ). The large limas with resistance, such as White Ventura N and UC 92, carry resistance to $M$. incognita reproduction and root galling but are susceptible to M. javanica. Among baby limas, two varieties (UC Cariblanco $\mathrm{N}$ vine baby lima and UC Beija-Flor bush baby lima) are available with resistance. These varieties carry a combination of three genes, providing resistance to $M$. incognita reproduction and root galling as well as to M. javanica root galling. Resistant varieties are much more tolerant of nematode infection and should be chosen when nematode infestation is known to exist in the field. Both resistant and susceptible lima beans should be grown in rotation with other crops that are nematode resistant or nonhosts (such as cereal grains), because these rotations minimize nematode buildup. Preseason soil sampling for estimating nematode presence and infestation levels can be helpful in guiding decisions on variety selection and rotation planning. The use of preplant nematicides is not economical for lima bean production. Other nematodes that infect lima beans include the lesion nematode, Pratylenchus scribneri, although it is not commonly associated with crop damage.

\section{HARVESTING}

Lima bean harvesting in California consists of cutting, windrowing, and threshing the crop, with each process requiring specialized equipment. To ensure yield and quality, weather conditions need to be monitored carefully during each harvesting step to avoid drying winds (to prevent shattering) or rain (to prevent discoloration and mold). Lima beans are generally grown as a single summer crop per year, needing a longer season to mature than common beans. Harvest of lima beans occurs in October and sometimes into November, depending on the planting date, the season, and the location. 


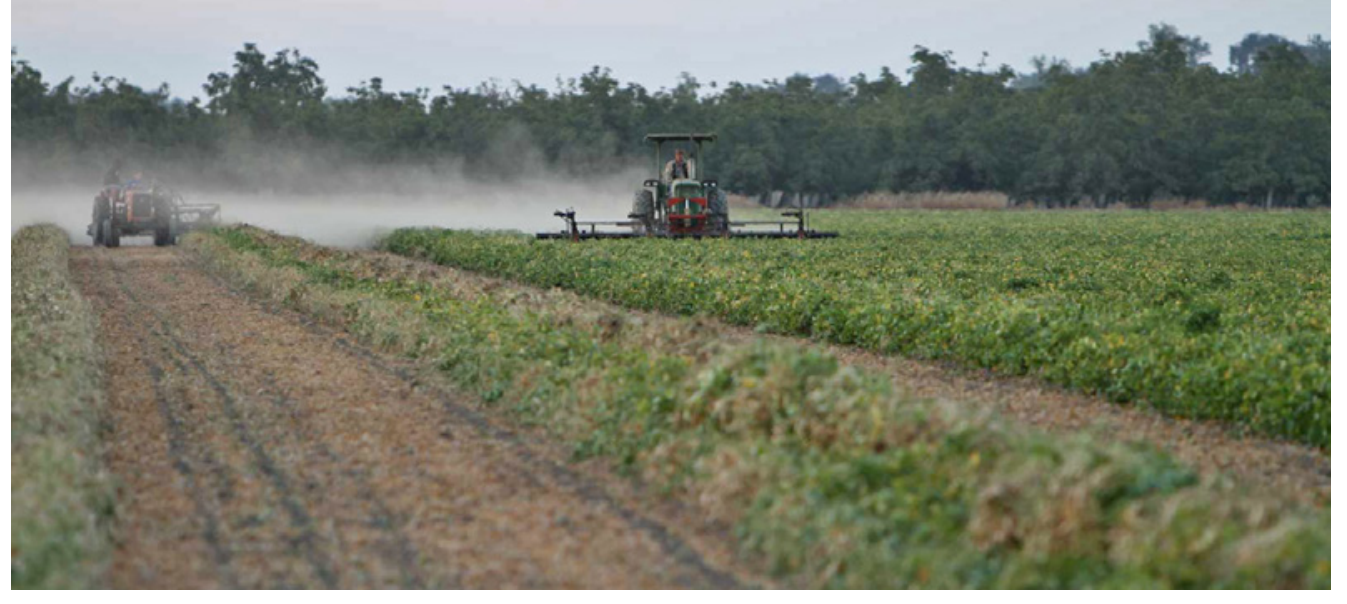

Cutting beans with a rotary cutter followed by windrowing. Photo: Courtesy of the California Dry Bean Advisory Board. or windrowed crop can cause severe reduction in bean quality, while low-humidity winds common in the fall can cause pod opening and seed loss. If windrowed beans are rained on, a side-delivery rake may be used to turn the windrow after the ground surface dries in an attempt to promote drying to avoid mold and discolored beans. Heavy winds can present a problem for lima beans that are windrowed and nearly dry enough to thresh, due to shattering of pods.

\section{Threshing}

Lima beans are generally threshed by specially designed bean threshers equipped with two or three slow-turning cylinders. California lima beans at harvest have dry pods and beans and relatively green stems. The two- and three-cylinder threshers can separate the pods and plant material (chaff) from the dry beans with very little damage to the bean.

Care must be taken in threshing lima beans because moisture in the seed can drop very quickly to 8 or 9 percent in the windrow, especially in windy conditions or with beans cut in August and September. At low moisture, beans become brittle and damage easily during threshing and handling or storage. Threshing should be done when beans in the windrow contain between 12 and 15 percent moisture. This is determined using a seed moisture meter, generally after collecting beans from a short trial harvest run. Thresher operators must be very aware of moisture and relative humidity changes during the day and night. A small change in threshing humidity can result in large effects on recovery and seed damage. Experienced harvesters often thresh only a few hours each day (and sometimes at night) when relative humidity and seed moisture are optimal.

Beans are handled in bulk in most California production regions. From the thresher, beans are transferred into trucks or trailers for transport to the warehouse. Beans are dumped from the back of truck beds with hydraulic lifts or from bottom-dump trailers into pits at the warehouse. Extreme care should be exercised in all bean-handling operations, from threshing to cleaning, because damage to the beans is cumulative. Cryptic (unapparent) damage to bean seeds has been shown to negatively affect germination, 
seedling vigor, and cooking characteristics. It is important to keep in mind that visual characteristics are perhaps the most important determinants affecting the price obtained for the crop. Beans grown as planting stock must be threshed and handled with even greater care to avoid damage to seed germination and seedling vigor.

\section{Cleaning, Grading, and Marketing}

Lima beans from the thresher often contain 5 to 30 percent "dirt," consisting of plant debris, small rocks and clods, bean pieces, and other foreign matter. Such debris, along with diseased, discolored, broken, split, and insect-damaged beans, must be removed. At the warehouse, beans are weighed, tested for moisture, and assigned a lot number. A subsample from each truckload is taken for future reference to that particular load. Beans are then dumped into a conveyor pit and transported through a scalper to remove most of the large and fine extraneous materials while en route to bins, where they are stored until they can be recleaned.

Beans are mechanically separated from debris during cleaning, usually by air-screen separators, gravity tables, de-stoners, aspirators, and, in some cases, textured rice rollers. Bean sizing may take place during the screening process. Beans destined for retail packaging are often polished using commercial polishing machines to remove fine dust and other imperfections from the surface of the bean. Beans destined for the canning industry are not typically polished. Beans in the warehouse are usually recleaned on a first-come, firstserved basis. Most California warehouses today use electronic color sorters to remove discolored beans and other contaminants not easily removed with traditional mechanical cleaning systems. Beans are typically packaged in 50- or 100-pound bags and put on pallets for shipment, or packaged in 2,000 pound totes that can be loaded directly onto trucks without palletization. The warehouse manager may serve as the broker or as an intermediary between the grower and broker for sales of lima beans.

Markets for California lima beans include the canning industry, the retail packaging industry, and international export (primarily to Japan). Most lima beans are grown under contract to processors and for package or bulk sales. As with other commodities, lima beans must meet federal grading standards found at the USDA Agricultural Marketing Service website, http://www.ams.usda.gov/AMSv1.0/standards.

\section{REFERENCES}

Ayers, R. S., and D. W. Westcot. 1994. Water quality for agriculture. FAO Irrigation and Drainage paper 29, Rev. 1.

California Bean Shippers Association website, http://www.calbeanshippers.org.

California Dry Bean Advisory Board website, http://calbeans.org.

Canevari, W. M., K. M. Klonsky, and R. L. De Moura. 2010. University of California Cooperative Extension sample costs to produce large lima beans in the northern San Joaquin Valley. UC Davis Agricultural and Resource Economics website, http://coststudies.ucdavis.edu.

Canevari, W. M., K. M. Klonsky, and R. L. De Moura. 2010. University of California Cooperative Extension sample costs to produce baby lima beans in the northern San Joaquin Valley. UC Davis Agricultural and Resource Economics website, http://coststudies.ucdavis.edu.

Hergert, G. W., and J. Schild. 2007. Fertilizer management for dry edible beans. Lincoln: University of Nebraska. NebGuide G1713. University of Nebraska-Lincoln Extension NebGuide website, http:/www.ianrpubs.unl. edu/pages/publicationD.jsp?publicationId=784.

Long, R. F., and J. Anderson. 2010. Establishing hedgerows on farms in California. Oakland: University of California Agriculture and Natural Resources Publication 8390. UC ANR CS website, http://anrcatalog.ucdavis.edu/Details.aspx?item $\mathrm{No}=8390$.

Long, R. F., S. R. Temple, J. L. Schmierer, W. M. Canevari, and R. Meyer. 2010 Common dry bean production in California. 2nd ed. Oakland: University of California Agriculture and Natural Resources Publication 8402. UC ANR CS website, http://anrcatalog.ucdavis.edu/Details.aspx?itemNo=8402.

Ritter, W. F., and R. W. Scarborough. 1992. Response of lima beans to irrigation on the Delmarva Peninsula. American Society of Agricultural Engineers 8(1): 23-27.

UC Agriculture and Natural Resources Grain Legume Workgroup website, http://beans.ucanr.org/.

USDA-NASS. U.S. Department of Agriculture National Agricultural Statistics Service (USDA-NASS) website, http://www.nass.usda.gov/.

UC IPM pest management guidelines: Color photo guide to dry bean pests. 1996. Oakland: University of California Agriculture and Natural Resources Publication 3339PS2.

UC IPM pest management guidelines for dry beans. UC IPM website, http://www.ipm.ucdavis.edu/PMG/selectnewpest.beans.html. 
Measurement Conversion TABle

\begin{tabular}{|l|c|c|l|}
\hline U.S. customary & $\begin{array}{c}\text { Conversion factor } \\
\text { for U.S. customary } \\
\text { to metric }\end{array}$ & $\begin{array}{c}\text { Conversion factor } \\
\text { for metric to U.S. } \\
\text { customary }\end{array}$ & Metric \\
\hline inch (in) & 2.54 & 0.394 & centimeter (cm) \\
\hline foot (ft) & 0.3048 & 3.28 & meter (m) \\
\hline gallon (gal) & 3.785 & 0.26 & liter (l) \\
\hline pound (lb) & 0.454 & 2.205 & kilogram (kg) \\
\hline
\end{tabular}

\section{PRECAUTIONS FOR USING PESTICIDES}

Pesticides are poisonous and must be used with caution. READ THE LABEL CAREFULLY BEFORE OPENING A PESTICIDE CONTAINER. Follow all label precautions and directions, including requirements for protective equipment. Use a pesticide only on crops specified on the label. Apply pesticides at the rates specified on the label or at lower rates if suggested in this publication. In California, all agricultural uses of pesticides must be reported. Contact your county agricultural commissioner for details. Laws, regulations, and information concerning pesticides change frequently, so be sure the publication you are using is up to date.

LEGAL RESPONSIBILITY. The user is legally responsible for any damage due to misuse of pesticides. Responsibility extends to effects caused by drift, runoff, or residues.

TRANSPORTATION. Do not ship or carry pesticides together with foods or feeds in a way that allows contamination of the edible items. Never transport pesticides in a closed passenger vehicle or in a closed cab.

STORAGE. Keep pesticides in original containers until used. Store them in a locked cabinet, building, or fenced area

where they are not accessible to children, unauthorized persons, pets, or livestock. DO NOT store pesticides with foods, feeds, fertilizers, or other materials that may become contaminated by the pesticides.

CONTAINER DISPOSAL. Dispose of empty containers carefully. Never reuse them. Make sure empty containers are not accessible to children or animals. Never dispose of containers where they may contaminate water supplies or natural waterways. Consult your county agricultural commissioner for correct procedures for handling and disposal of large quantities of empty containers.

PROTECTION OF NONPEST ANIMALS AND PLANTS. Many pesticides are toxic to useful or desirable animals, including honey bees, natural enemies, fish, domestic animals, and birds. Crops and other plants may also be damaged by misapplied pesticides. Take precautions to protect nonpest species from direct exposure to pesticides and from contamination due to drift, runoff, or residues. Certain rodenticides may pose a special hazard to animals that eat poisoned rodents.

POSTING TREATED FIELDS. For some materials, reentry intervals are established to protect field workers. Keep workers out of the field for the required time after application and, when required by regulations, post the treated areas with signs indicating the safe reentry date.

HARVEST INTERVALS. Some materials or rates cannot be used in certain crops within a specific time before harvest.

Follow pesticide label instructions and allow the required time between application and harvest.

PERMIT REQUIREMENTS. Many pesticides require a permit from the county agricultural commissioner before possession or use. When such materials are recommended in this publication, they are marked with an asterisk $\left(^{*}\right)$.

PROCESSED CROPS. Some processors will not accept a crop treated with certain chemicals. If your crop is going to a processor, be sure to check with the processor before applying a pesticide.

CROP INJURY. Certain chemicals may cause injury to crops (phytotoxicity) under certain conditions. Always consult the label for limitations. Before applying any pesticide, take into account the stage of plant development, the soil type and condition, the temperature, moisture, and wind direction. Injury may also result from the use of incompatible materials. PERSONAL SAFETY. Follow label directions carefully. Avoid splashing, spilling, leaks, spray drift, and contamination of clothing. NEVER eat, smoke, drink, or chew while using pesticides. Provide for emergency medical care IN ADVANCE as required by regulation.

\section{FOR MORE INFORMATION}

To order or obtain ANR publications and other products, visit the ANR Communication Services online catalog at http://anrcatalog.ucanr.edu or phone 1-800-994-8849. You can also place orders by mail or FAX, or request a printed catalog of our products from

\section{University of California}

Agriculture and Natural Resources

Communication Services

1301 S. 46th Street

Building 478 - MC 3580

Richmond, CA 94804-4600

Telephone 1-800-994-8849

510-665-2195

FAX 510-665-3427

E-mail: anrcatalog@ucanr.edu

(C2014 The Regents of the University of California

Agriculture and Natural Resources

All rights reserved.

Publication 8505

ISBN-13: 978-1-60107-860-5

The University of California Division of Agriculture \& Natural Resources (ANR) prohibits discrimination against or harassment of any person participating in any of ANR's programs or activities on the basis of race, color, national origin, religion, sex, gender identity, pregnancy (which includes pregnancy, childbirth, and medical conditions related to pregnancy or childbirth), physical or mental disability, medical condition (cancer-related or genetic characteristics), genetic information (including family medical history), ancestry, marital status, age, sexual orientation, citizenship, or service in the uniformed services (as defined by the Uniformed Services Employment and Reemployment Rights Act of 1994: service in the uniformed services includes membership, application for membership, performance of service, application for service, or obligation for service in the uniformed services) or any person in any of its programs or activities.

University policy also prohibits retaliation against any employee or person participating in any of ANR's programs or activities for bringing a complaint of discrimination or harassment pursuant to this policy. This policy is intended to be consistent with the provisions of applicable State and Federal laws.

Inquiries regarding the University's equal employment opportunity policies may be directed to Linda Marie Manton, Affirmative Action Contact, University of California Agriculture and Natural Resources, 2801 Second Street, Davis, CA, 95618-7774, 530-750-1318. For information about ordering this publication, telephone 1-800-994-8849.

To simplify information, trade names of products have been used. No endorsement of named or illustrated products is intended, nor is criticism implied of similar products that are not mentioned or illustrated.

An electronic copy of this publication can be found at the ANR Communication Services catalog website, http://anrcatalog.ucanr.edu/.

UC This publication has been anonymously peer reviewed for technical accuracy by

PEEE University of California scientists and other qualified professionals. This review process REVIEWED was managed by ANR Associate Editor for Urban Pest Management, Mary Louise Flint. 